\title{
Petrology of spinel harzburgite xenoliths from the Kishb Plateau, Saudi Arabia
}

\author{
Lung-Chuan Kuo* and Eric J. Essene \\ Department of Geological Sciences, University of Michigan, Ann Arbor, MI 48109, USA
}

\begin{abstract}
Two spinel harzburgite xenoliths from a Pleistocene alkali basalt unit erupted at the northwestern corner of the Tertiary Kishb Plateau (Saudi Arabia) are characterized by an incipient transition from protogranular to porphyroclastic texture. Vermicular and interstitial spinels are closely associated with neoblasts of olivine, enstatite, and diopside. Sparse exsolution lamellae of high-Ca pyroxene occur in all the enstatite porphyroblasts. Olivine neoblasts are, in many cases, in contact with one another, with the triple grain junctions rarely approaching $120^{\circ}$. Chemical zoning is undetectable by microprobe in spinel and olivine, whereas zoning of $\mathrm{Al}$ in enstatite and diopside indicates that chemical equilibrium was not attained. Clear, palegreen glasses occur as veinlets about 10 microns or less in width along grain boundaries and cracks. Consistent counting rates for $\mathrm{Na}$ in these glasses were obtained only at $5 \mathrm{kV}$ with a sample current of about 6 namps and counting time of less than $7 \mathrm{~s}$. These glasses are chemically homogeneous and are characterized by relatively high contents of $\mathrm{SiO}_{2}$ $(55.8-58.7 \mathrm{wt} \%), \quad \mathrm{Na}_{2} \mathrm{O} \quad(6.4-7.6 \mathrm{wt} \%), \quad$ and $\mathrm{Al}_{2} \mathrm{O}_{3}$ $(20.0-21.6 \mathrm{wt} \%)$, with inferred volatile contents of less than $1 \mathrm{wt} \%$. The glass is suggested to be of upper mantle origin rather than having developed from the host basalt or by decompressional melting upon ascent.

Geothermometry and geobarometry indicate that the lithospheric upper mantle beneath the Arabian Shield had been locally heated to higher than $1,050^{\circ} \mathrm{C}$ during Miocene/ Pliocene, resulting in some degree of partial melting. Spinel was formed by reaction between aluminous pyroxenes and olivine during subsequent cooling, and intercrystalline $\mathrm{Mg}-\mathrm{Fe}$ exchange reached a steady state at about $800^{\circ} \mathrm{C}$. The geotherm beneath the Arabian Shield since Miocene is estimated to be somewhat lower than that representing the present oceanic upper mantle. The thermal history established is consistent with the tectonic history of the Red Sea area and indicates a two-stage magmatism in the Arabian Shield since Miocene.
\end{abstract}

\section{Introduction}

Cenozoic volcanism is an important part of the tectonics of the western Arabian subcontinent. Gregory et al. (1982)

\footnotetext{
* Present address: 6467 RDW, Conoco Inc., 1000 South Pine, Ponca City, OK 74601, USA

Offprint requests to: L.-C. Kuo
}

divided the volcanic activity into two stages: the OligoceneMiocene stage characterized by the eruption of dominantly unfractionated alkali basalts forming an array of basalt plateaus parallel to the median axis of the Red Sea (Fig. 1) and the Quaternary stage marked by the sporadic eruption of small amounts of hawaiitic and silicic lavas with minor alkali olivine basalts. The earlier stage of volcanism is suggested to be related to the initial opening of the Red Sea, and the later one to the development of the rift system of the Red Sea (Ghent et al. 1980; Gregory et al. 1982).

The alkali basalts of both stages contain ultramafic xenoliths. Petrological studies have been made for the xenoliths from the Birk area (Ghent et al. 1980) and from the Kishb Plateau (Vaughan 1985) (Fig. 1). This paper presents the petrology of spinel harzburgite xenoliths from the Kishb Plateau and discusses its bearing on the thermal evolution of the upper mantle beneath the Arabian Shield.

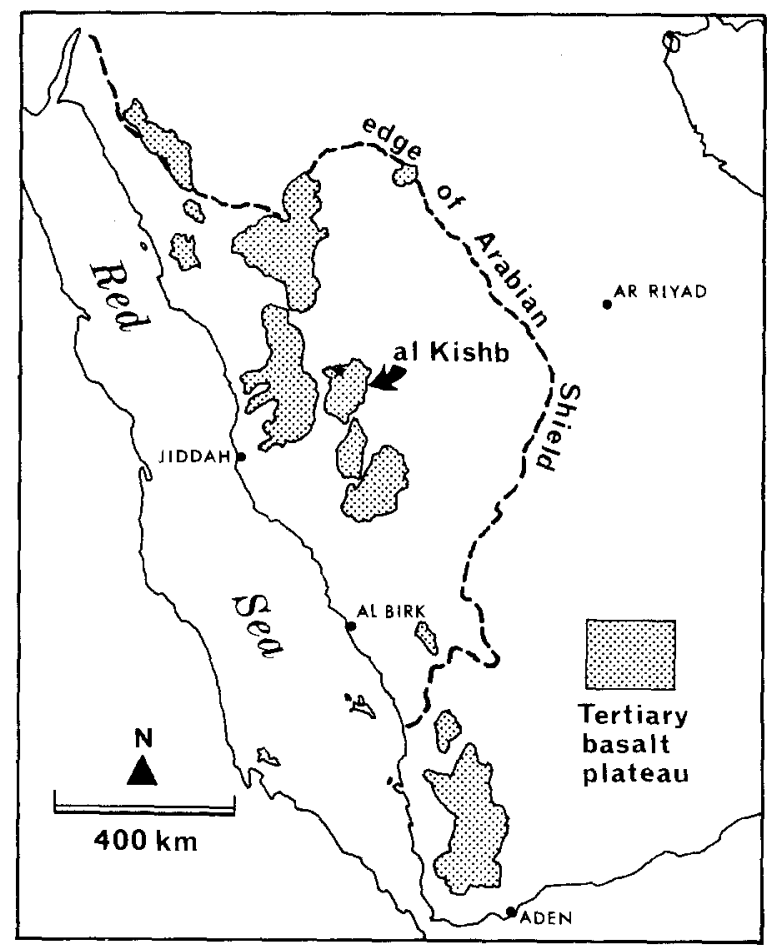

Fig. 1. Distribution of Tertiary basalt plateaus in the western Arabian subcontinent. Sample locality is shown by the star 


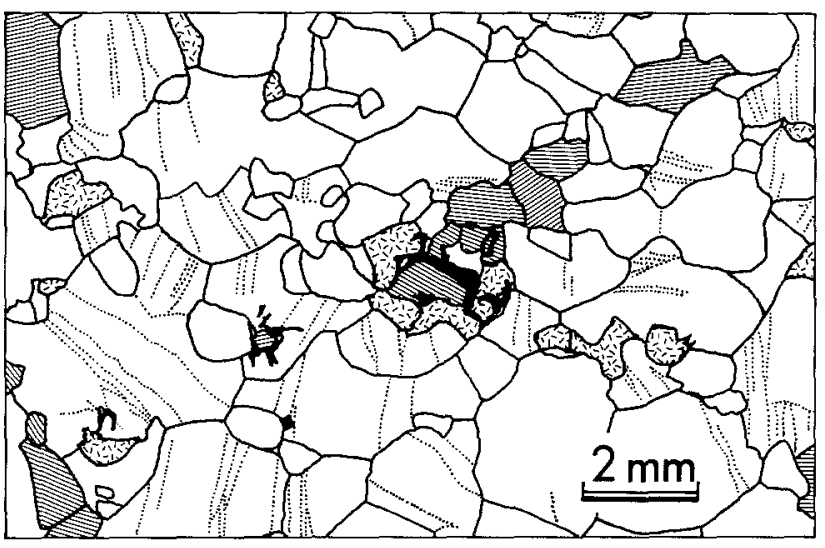

Fig. 2. A sketch after thin section showing the typical texture of the sample HAK-1. Blank with dotted lines: olivine with deformation bands and subgrain boundaries; dashes: diopside; parallel lines: enstatite with cleavage; black: spinel

A Pleistocene alkali basalt unit, about $200 \mathrm{~km}^{2}$ in area, covers the northwest corner of the Kishb Plateau which is composed mainly of Tertiary alkali basalt flows (Kemp et al. 1982). This unit, extruded from a fracture zone and erupted explosively to form a cinder cone (Mt. Aslaj, star in Fig. 1), contains peridotite and less abundant spinel clinopyroxenite xenoliths. The two samples studied here are from the west flank of Mt. Aslaj. These subspherical, 7-9-cm-diameter xenoliths are wrapped in a $0.5-1-\mathrm{cm}$-thick skin of alkali basalt. The composition of the host basalt is given in Table 1 .

\section{Petrography}

The two hand specimens of harzburgites (HAK-1 and HAK-2) show very similar mineralogy with a bimodal distribution of grain size. Fresh, light-green, equant to subequant olivine and brownishblack, subequant to tabular enstatite grains are 1 to $5 \mathrm{~mm}$ across (porphyroblasts), whereas light-green olivine, colorless enstatite, and reddish-brown spinel grains are $2 \mathrm{~mm}$ or less across (neoblasts). Chrome-green diopside grains are generally about $1 \mathrm{~mm}$ across.

In thin section, the curvilinear boundaries between porphyroblasts are often disturbed by neoblasts. Most olivine porphyroblasts show undulose extinction and have deformation bands. A weak foliation (horizontal in Fig. 2) is defined by the elongation of olivine grains, with deformation bands approximately perpendicular to it. Sparse exsolution lamellae of high-Ca pyroxene are ubiquitous inside the enstatite porphyroblasts. Only the rims (about $0.1 \mathrm{~mm}$ thick) of these enstatites are free of exsolution lamellae. Diopside are either associated with enstatite plus spinel plus olivine or completely surrounded by olivine.

Polygonal to subrounded olivine neoblasts are usually located at boundaries of porphyroblasts and are free of deformation fea-
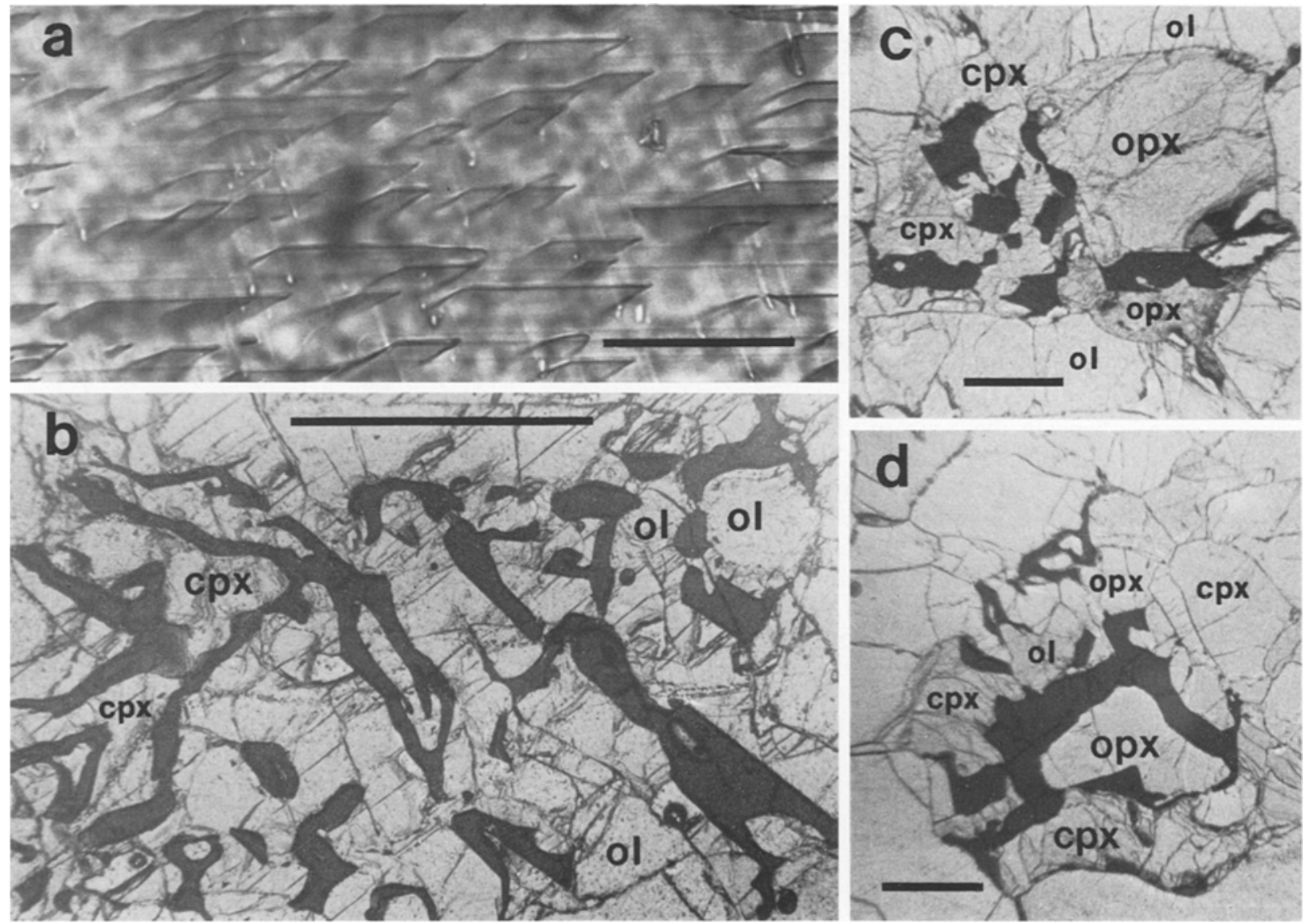

Fig. 3a-d. Transmitted light photomicrographs showing the morphologies and occurrences of spinels. All photos are taken from the sample HAK-1. a Spinel platelets colinear with the [001] cleavage of the host enstatite porphyroblast. Scale bar: $0.05 \mathrm{~mm}$. b Vermicular spinel (black) sitting at one end of an enstatite porphyroblast and partially enclosing olivine (ol) and diopside (cpx) neoblasts. Scale bar: $1 \mathrm{~mm}$. c, d Interstitial spinels (black) associated with olivine (ol), enstatite (opx), and diopside (cpx) neoblasts. Scale bars: $1 \mathrm{~mm}$ 


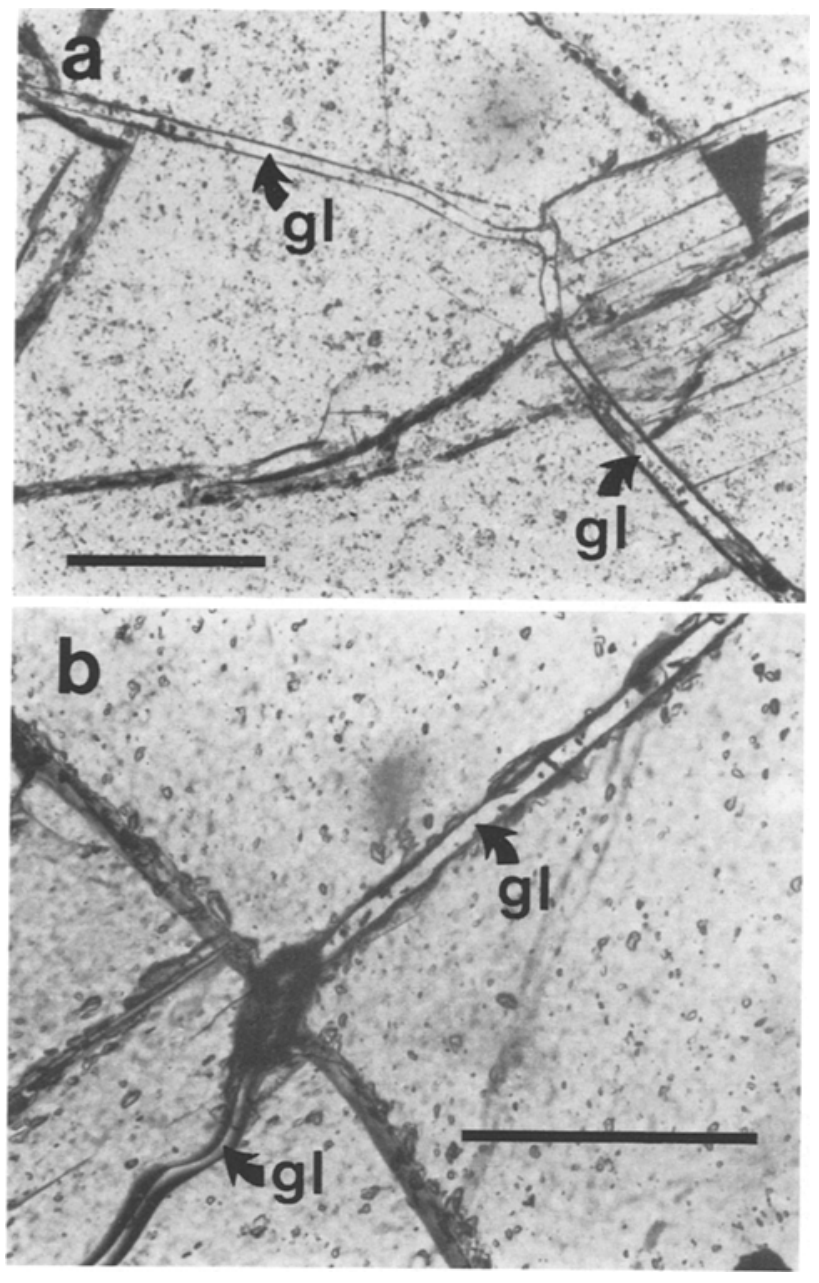

Fig. 4a, b. Transmitted light photomicrographs illustrating the occurrences of interstitial glasses $(\mathrm{g} l)$. Scale bars: $0.2 \mathrm{~mm}$. a A glass veinlet passing through the boundaries of two olivine grains (upper and lower) and the olivine (lower) and diopside (right, with cleavage) crystals. Sample HAK-1. b A curvilinear glass veinlet penetrating two olivine grains and another thinner veinlet in the olivine at lower left. The boundary of the two olivine grains is perpendicular to the passage. Sample HAK-2

tures. These grains, representing about $10 \%$ of each sample, are usually in contact with one another, but a $120^{\circ}$ triple grain junction is rare. Irregularly shaped diopside and enstatite neoblasts are devoid of optically visible exsolution lamellae and are typically surrounded by olivine. The [001] direction of the enstatite neoblasts tend to be parallel to the foliation. Neoblastic spinels exhibit two distinct textural types. The first type occurs as dense arrays of light-green platelets aligned parallel to the [001] of the host enstatite porphyroblast (Fig. 3a) and represents exsolution (Basu and MacGregor 1975). The second type occurs as vermicular grains inside the enstatite closely associated with olivine and diopside neoblasts (Fig. 3 b), or as interstitial grains between the neoblasts (Fig. 3c,d). Spinel neoblasts show no preferred orientation.

The texture of the Kishb xenoliths differ from protogranular texture only by the presence of olivine neoblasts. The mineral foliation and lineation are too weak, the number of olivine neoblasts too small, and the density of deformation bands in olivine porphyroblasts too low to be defined as a porphyroclastic texture (Mercier and Nicolas 1975). We suggest that these features represent an incipient transition from protogranular to porphyroclastic texture. This transitional texture is the result of intracrystalline glide being the dominant mode of deformation.
Table 1. Bulk compositions of the spinel harzburgite (HAK-1) and the host alkali basalt

\begin{tabular}{lcc}
\hline & HAK-1 & Host basalt \\
\hline $\mathrm{SiO}_{2}$ & 43.80 & 44.35 \\
$\mathrm{TiO}_{2}$ & 0.05 & 2.91 \\
$\mathrm{Al}_{2} \mathrm{O}_{3}$ & 1.49 & 17.65 \\
$\mathrm{Cr}_{2} \mathrm{O}_{3}$ & 0.45 & 0.02 \\
$\mathrm{FeO}^{\mathrm{a}}$ & 7.77 & 12.68 \\
$\mathrm{MnO}$ & 0.13 & 0.06 \\
$\mathrm{MgO}$ & 44.70 & 4.97 \\
$\mathrm{CaO}$ & 0.91 & 9.70 \\
$\mathrm{NiO}$ & nd & 0.09 \\
$\mathrm{Na}_{2} \mathrm{O}$ & 0.16 & 5.29 \\
$\mathrm{~K}_{2} \mathrm{O}$ & 0.03 & 1.64 \\
$\mathrm{P}_{2} \mathrm{O}_{5}$ & 0.02 & 0.72 \\
\hline Total & 99.51 & 100.08 \\
\hline
\end{tabular}

Norm (wt \%)

$\begin{array}{lrc}\text { or } & 0.17 & 9.68 \\ \mathrm{ab} & 1.36 & 13.83 \\ \mathrm{an} & 3.28 & 19.56 \\ \text { ne } & - & 16.73 \\ \mathrm{di} & 0.81 & 12.97 \\ \text { hd } & 0.07 & 6.39 \\ \text { en } & 15.19 & - \\ \text { fs } & 1.66 & - \\ \text { fo } & 67.81 & 4.45 \\ \text { fa } & 8.22 & 2.77 \\ \text { mt } & 0.63 & 6.38 \\ \text { chr } & 0.67 & 0.02 \\ \text { ilm } & 0.09 & 5.52 \\ \text { ap } & 0.04 & 1.70\end{array}$

a Total $\mathrm{Fe}$ as $\mathrm{FeO}$. For norm calculations: $\mathrm{Fe}_{2} \mathrm{O}_{3}=\mathrm{TiO}_{2}+1.5$ (wt \%) for basalt (Irvine and Baragar 1971), and $\mathrm{Fe}^{3+} / \mathrm{Fe}^{2+}=0.1$ for spinel harzburgite

Clear, pale-green glasses occur as veinlets along grain boundaries (Fig. 4a) or cracks inside the grains (Fig. 4b). These veinlets are typically about 10 microns or less in width and, in some cases, contain tiny patches of high-relief material. The veinlets, with their widths unrelated to the adjacent mineral species, are randomly distributed throughout the sample and, in some cases, are continuous along several grain boundaries. The source of these glasses is difficult to identify (cf. Maaløe and Printzlau 1979). The glasscrystal contacts are smooth, without the evidence of corrosion of the crystal faces by the liquid. No features indicative of the presence of vapor can be identified.

At the contact of xenolith and host rock, preferential dissolution of pyroxenes over olivine results in the curvilinear indentation of the pyroxene-host rock boundary up to about $1 \mathrm{~mm}$ deep. This feature was described in detail by Kuo and Kirkpatrick (1985).

In the sample HAK-1, the basaltic melt penetrates no deeper than about $2 \mathrm{~mm}$ into the xenolith along grain boundaries and intragranular cracks. The glass is light brown in color and is partially devitrified. Bundles of olivine belonites are developed within several larger, wedged openings. The penetration of basaltic melt is, however, at least $1 \mathrm{~cm}$ deep in the sample HAK-2. In this sample, patches of dense, wormy inclusions (typically a few microns or less in size) are present in some olivine grains near the xenolithbasalt contact. The small inclusions are filled with dark material. Several larger ones show features similar to those described by Roedder (1965, Fig. 8).

The host basalt is vesicular and exhibits porphyritic texture. Olivine phenocrysts are euhedral, equant and, in many cases, show a hopper morphology. Plagioclase and pyroxene phenocrysts are rare. The groundmass is composed of basalt glass, with small 
Table 2. Comparison of the modal compositions of the sample HAK-1 obtained from point-counting and from calculation using compositions of wholerock and constituent phases

\begin{tabular}{lrlrr}
\hline & 1 & 2 & 3 & \multicolumn{1}{l}{4} \\
\hline Olivine & 75.03 & 3.21 & 74.56 & 74.89 \\
Enstatite & 19.43 & 3.27 & 19.67 & 19.64 \\
Diopside & 4.61 & 3.25 & 4.64 & 3.37 \\
Spinel & 0.89 & 3.98 & 1.09 & 1.40 \\
Glass & 0.04 & 2.76 & 0.04 & 0.70 \\
\hline
\end{tabular}

$1=$ the modal composition (vol\%) from point-counting in 4 thin sections

$2=$ estimated densities of phases $\left(\mathrm{g} / \mathrm{cm}^{3}\right)$

$3=$ the modal composition ( $w \mathrm{t} \%$ ) derived from 1 and 2

$4=$ the modal composition (wt $\%$ ) calculated from the mineral and whole-rock compositions

amount of subhedral olivine microlites and very few plagioclase laths. Large grains of olivine, pyroxene, and spinel are present in the basalt, which are apparently derived from the xenoliths (see also Fujii and Scarfe 1982).

Because of considerable contamination of the sample HAK-2 by the host basalt, the whole-rock composition and modal analysis were obtained only for the sample HAK-1. The results (Tables 1 and 2) show that the rock is a harzburgite. The percentage of glass in the mode is uncertain because some may have been lost by plucking. In order to check this, we have converted our measured mode into wt $\%$ mode using the estimated densities of phases, and have calculated the wt $\%$ mode from the whole-rock analysis and averaged composition of each phase using a least squares program from the University of Michigan MIDAS package. The calculated mode is in good agreement with the measured mode except for the higher glass content $(0.70$ versus $0.04 \mathrm{wt} \%$; Table 2$)$. The calculated amount of glass is more reliable because alkalis are virtually absent in the mineral phases, so the alkali content of the xenolith is strictly a function of the glass content.

\section{Mineral and interstitial glass compositions}

\section{Analytical methods}

Quantitative analyses of 7 to 10 grains of each coexisting neoblastic phase and several porphyroblastic enstatite and olivine grains in the sample HAK-1 have been performed on the University of Michigan ARL-EMX electron microprobe with wavelength dispersive PET, LiF, and TAP crystal spectrometers. Typically 3 to 6 analyses were made in one grain. The operating conditions were: accelerating voltage, $15 \mathrm{kV}(12 \mathrm{kV}$ for any batch including $\mathrm{Na}$ ); sample current, 8 to 10 namps; beam diameter, 1 to 2 microns; counting time, 20 to $35 \mathrm{~s}$. A beam diameter of about 10 microns was used for integrated analyses for $\mathrm{Ca}, \mathrm{Fe}$, and $\mathrm{Mg}$ over the central part of the enstatite porphyroblasts to evaluate the extent of high-Ca pyroxene exsolution. Well-analyzed natural minerals were used as standards. The matrix correction of the data was made with the programm EMPADR VII (Rucklidge and Gasparrini 1969). The analytical errors resulting from counting statistics are within $0.5 \%$ relative and up to $2.0 \%$ relative, respectively, for major and minor elements.

Preliminary microprobe tests revealed a rapid loss of $\mathrm{Na}$ in the interstitial glasses. Maximum, consistent counts (less than $2 \%$ deviation) were only obtained at an accelerating voltage of $5 \mathrm{kV}$, sample current of 6 namps, and counting time of about $7 \mathrm{~s}$. These conditions yield nearly 6,000 counts in a cycle, and thus the data for $\mathrm{Na}$ were collected typically for 4 cycles. Although the samples and standards were coated simultaneously to minimize the effects of carbon film thickness on analytical precision, the error for $\mathrm{Na}$ is inevitably larger than that for other elements (perhaps up to
Table 3. Representative microprobe analyses of olivine neoblasts (columns 1-4) and porphyroblasts (columns 5 and 6). Sample designation (Tables 3-6): capital letters identify the thin sections; each number indicates an area in that thin section. Analyses with identical sample designations are used for geothermometry

\begin{tabular}{lrrrrrr}
\hline Sample no. & \multicolumn{1}{c}{$\mathrm{A} 2$} & \multicolumn{1}{c}{$\mathrm{A} 3$} & \multicolumn{1}{c}{$\mathrm{B} 1$} & $\mathrm{C} 1$ & \multicolumn{1}{c}{$\mathrm{B} 3$} & \multicolumn{1}{c}{$\mathrm{C} 3$} \\
\hline $\mathrm{SiO}_{2}$ & 40.87 & 41.08 & 40.73 & 40.62 & 41.09 & 40.92 \\
$\mathrm{FeO}$ & 8.97 & 8.80 & 8.36 & 8.57 & 8.57 & 8.61 \\
$\mathrm{MgO}$ & 50.12 & 49.88 & 49.46 & 49.58 & 50.14 & 49.67 \\
$\mathrm{MnO}$ & 0.20 & 0.19 & 0.17 & 0.20 & 0.21 & 0.18 \\
$\mathrm{CaO}$ & 0.06 & 0.07 & 0.07 & 0.04 & 0.05 & 0.05 \\
$\mathrm{NiO}$ & 0.36 & 0.38 & 0.35 & 0.37 & 0.35 & 0.36 \\
\hline Total & 100.58 & 100.40 & 99.14 & 99.38 & 100.41 & 99.79 \\
\hline $\mathrm{Si}$ & 0.992 & 0.999 & 1.002 & 0.998 & 0.998 & 1.001 \\
$\mathrm{Fe}$ & 0.182 & 0.179 & 0.172 & 0.176 & 0.174 & 0.176 \\
$\mathrm{Mg}_{\mathrm{Mn}}$ & 1.813 & 1.808 & 1.813 & 1.814 & 1.816 & 1.810 \\
$\mathrm{Ca}$ & 0.004 & 0.004 & 0.004 & 0.004 & 0.004 & 0.004 \\
$\mathrm{Ni}$ & 0.002 & 0.002 & 0.002 & 0.001 & 0.001 & 0.002 \\
\hline $\mathrm{Molec} \%$ & 0.007 & 0.008 & 0.007 & 0.007 & 0.007 & 0.007 \\
$\mathrm{Mg}_{2} \mathrm{SiO}_{4}$ & & & & & & \\
$\mathrm{Fe}_{2} \mathrm{SiO}_{4}$ & 90.29 & 90.35 & 90.74 & 90.61 & 90.71 & 90.55 \\
$\mathrm{Ni}_{2} \mathrm{SiO}_{4}$ & 9.06 & 8.95 & 8.61 & 8.79 & 8.69 & 8.80 \\
$\mathrm{Ca}_{2} \mathrm{SiO}_{4}$ & 0.35 & 0.40 & 0.35 & 0.35 & 0.35 & 0.35 \\
$\mathrm{Mn}_{2} \mathrm{SiO}_{4}$ & 0.10 & 0.10 & 0.10 & 0.05 & 0.05 & 0.10 \\
\hline & 0.20 & 0.20 & 0.20 & 0.20 & 0.20 & 0.20 \\
\hline & & & & & &
\end{tabular}

a few percent relative; see Reed 1975, p. 180-181). However, because much more $\mathrm{Na}$ is lost due to volatilization than to the application of low accelerating voltage, it is very likely that many published analyses on glasses may have underestimated $\mathrm{Na}$ contents. Data on all other elements in the glasses were collected at $10 \mathrm{kV}$. The beam, with a diameter of 1-2 microns, was located precisely because the glasses are weakly fluorescent. The standards used, the procedure of data reduction, and the analytical accuracy are the same as those described above.

\section{Olivine}

Because of their homogeneity, two to three point analyses in a given grain were averaged to obtain one composition. The compositions of neoblastic olivines (first 4 columns in Table 3 ) are $\mathrm{Fo}_{90.3-90.8}$, which are identical to those of porphyroblastic olivines $\left(\mathrm{Fo}_{90.3-90.7}\right)$. The NiO contents of both kinds of olivines have a range of $0.34-0.38 \mathrm{wt} \%$.

\section{Enstatite}

The analyses of enstatites were normalized to 4 cations and the numbers of 4- and 6-coordinated Al cations were calculated using the formula

$\mathrm{Cr}-\mathrm{Na}+\mathrm{Al}^{\mathrm{VI}}=\mathrm{Al}^{\mathrm{IV}}-2 \mathrm{Ti}$.

This adjusts the number of $\mathrm{Si}$ cations and makes the total iron ferrous. Neoblastic enstatites (columns 1 to 4 , Table 4) have a narrow composition range $\left(\mathrm{En}_{87.2-86.5} \mathrm{Fs}_{8.6-8.4} \mathrm{Wo}_{1.1-0.9}\right)$, whereas the rims of porphyroblastic enstatites have distinctively higher En and lower Wo contents $\left(\mathrm{En}_{88.0-87.1} \mathrm{Fs}_{8.4-8.3} \mathrm{Wo}_{0.8-0.6}\right)$ and, on average, lower $\mathrm{Al}_{2} \mathrm{O}_{3}$ contents. Integrated analyses show that the $\mathrm{Ca}$ contents over the central part of the enstatite porphyroblasts correspond to less than $1 \%$ (vol.) of exsolution lamellae. Thus, the chemical differences described above can be attributed to the exsolution of diopside and spinel, if one assumes that the bulk compositions of enstatite neoblasts and porphyroblasts are identical.

Variations in $\mathrm{MgO}$ and $\mathrm{FeO}$ contents in any given grain are 
Table 4. Representative microprobe analyses of enstatite neoblasts (columns 1-4) and the rims of porphyroblasts (columns 5 and 6)

\begin{tabular}{|c|c|c|c|c|c|c|}
\hline Sample no. & A 3 & B1 & $\mathrm{B} 2$ & $\mathrm{C} 1$ & A6 & B 5 \\
\hline $\mathrm{SiO}_{2}$ & 56.61 & 56.42 & 56.82 & 56.56 & 56.56 & 56.47 \\
\hline $\mathrm{TiO}_{2}$ & na & na & na & na & 0.17 & 0.18 \\
\hline $\mathrm{Al}_{2} \mathrm{O}_{3}$ & 2.90 & 3.01 & 2.76 & 2.72 & 2.86 & 2.64 \\
\hline $\mathrm{Cr}_{2} \mathrm{O}_{3}$ & 0.50 & 0.41 & 0.38 & 0.46 & 0.34 & 0.33 \\
\hline $\mathrm{FeO}$ & 5.79 & 5.71 & 5.63 & 5.69 & 5.69 & 5.66 \\
\hline $\mathrm{MgO}$ & 34,01 & 33.58 & 33.88 & 34.03 & 33.78 & 34.43 \\
\hline $\mathrm{MnO}$ & na & na & na & na & 0.22 & 0.23 \\
\hline $\mathrm{CaO}$ & 0.57 & 0.50 & 0.53 & 0.54 & 0.49 & 0.45 \\
\hline $\mathrm{NiO}$ & 0.10 & 0.11 & 0.10 & 0.09 & na & na \\
\hline $\mathrm{Na}_{2} \mathrm{O}$ & 0.11 & 0.11 & 0.14 & 0.11 & 0.07 & 0.06 \\
\hline Total & 100.59 & 99.85 & 100.24 & 100.20 & 100.18 & 100.45 \\
\hline $\mathrm{Si}$ & 1.938 & 1.937 & 1.942 & 1.942 & 1.938 & 1.939 \\
\hline $\mathrm{A} 1^{\mathrm{IV}}$ & 0.062 & 0.063 & 0.058 & 0.058 & 0.062 & 0.061 \\
\hline $\mathrm{Al}^{\mathrm{VI}}$ & 0.054 & 0.060 & 0.057 & 0.053 & 0.055 & 0.045 \\
\hline $\mathrm{Ti}$ & - & - & - & - & 0.004 & 0.005 \\
\hline $\mathrm{Cr}$ & 0.015 & 0.013 & 0.012 & 0.014 & 0.010 & 0.010 \\
\hline $\mathrm{Fe}^{2+}$ & 0.166 & 0.166 & 0.163 & 0.163 & 0.165 & 0.162 \\
\hline Mg & 1.733 & 1.731 & 1.737 & 1.739 & 1.737 & 1.750 \\
\hline $\mathrm{Mn}$ & - & - & - & - & 0.007 & 0.007 \\
\hline $\mathrm{Ca}$ & 0.021 & 0.019 & 0.019 & 0.020 & 0.019 & 0.017 \\
\hline $\mathrm{Ni}$ & 0.003 & 0.003 & 0.003 & 0.003 & - & - \\
\hline $\mathrm{Na}$ & 0.008 & 0.008 & 0.009 & 0.008 & 0.003 & 0.004 \\
\hline \multicolumn{7}{|l|}{ Molec. $\%$} \\
\hline $\mathrm{Mg}_{2} \mathrm{Si}_{2} \mathrm{O}_{6}$ & 86.54 & 86.61 & 86.97 & 86.88 & 87.15 & 87.91 \\
\hline $\mathrm{Fe}_{2} \mathrm{Si}_{2} \mathrm{O}_{6}$ & 8.59 & 8.59 & 8.41 & 8.47 & 8.53 & 8.38 \\
\hline $\mathrm{Ca}_{2} \mathrm{Si}_{2} \mathrm{O}_{6}$ & 1.09 & 0.94 & 0.99 & 1.03 & 0.78 & 0.62 \\
\hline $\mathrm{MgAl}_{2} \mathrm{SiO}_{6}$ & 2.85 & 3.07 & 2.85 & 2.74 & 2.86 & 2.33 \\
\hline $\mathrm{MgCrAlSiO}_{6}$ & 0.36 & 0.21 & 0.16 & 0.31 & 0.36 & 0.31 \\
\hline $\mathrm{NaCrSi}_{2} \mathrm{O}_{56}$ & 0.41 & 0.42 & 0.47 & 0.41 & 0.16 & 0.20 \\
\hline $\mathrm{CaTiAl}_{2} \mathrm{O}_{6}$ & - & - & - & - & 0.16 & 0.25 \\
\hline $\mathrm{Ni}_{2} \mathrm{Si}_{2} \mathrm{O}_{6}$ & 0.16 & 0.16 & 0.15 & 0.16 & - & - \\
\hline
\end{tabular}

less than $0.6 \%$ relative, and the $\mathrm{Mg} /(\mathrm{Mg}+\mathrm{Fe})$ ratios of neoblastic enstatites are slightly higher than those of the coexisting olivines. The $\mathrm{Al}_{2} \mathrm{O}_{3}$ contents, however, are more variable (Fig. 5). The standard deviations for $\mathrm{Al}_{2} \mathrm{O}_{3}$ and $\mathrm{Cr}_{2} \mathrm{O}_{3}$ contents are less than $0.13 \mathrm{wt} \%$ and $0.09 \mathrm{wt} \%$, respectively. The variations in $\mathrm{Al}_{2} \mathrm{O}_{3}$ and $\mathrm{Cr}_{2} \mathrm{O}_{3}$ contents in each xenolith are comparable to those found in enstatites in Calton Hill xenoliths (Donaldson 1978).

\section{Diopside}

After normalizing to 4 cations, the ferric iron was calculated using the formula

$\mathrm{Fe}^{3+}=\mathrm{Na}+\mathrm{Al}^{\mathrm{IV}}-\mathrm{Al}^{\mathrm{VI}}-2 \mathrm{Ti}-\mathrm{Cr}$

and allocated to acmite component. All the Na left from ureyite and acmite components was assigned to jadeite component.

The diopsides in this xenolith are chromian diopsides (Table 5) which are compositionally more variable $\left(\operatorname{En}_{48.3-46.6} \mathrm{Wo}_{41.6-}\right.$ $\left.{ }_{40.8} \mathrm{Fs}_{3.1}-0.2\right)$ than enstatites. Within a given grain, the $\mathrm{Na}_{2} \mathrm{O}$ and $\mathrm{TiO}_{2}$ contents are more uniform than $\mathrm{Al}_{2} \mathrm{O}_{3}$ and $\mathrm{CaO}$ contents, and slight zoning of $\mathrm{Al}_{2} \mathrm{O}_{3}$ is present (Fig. 6). The positive correlation between $\mathrm{Al}_{2} \mathrm{O}_{3}$ and $\mathrm{Cr}_{2} \mathrm{O}_{3}$ is also found in other zoned diopside grains (e.g., Quick 1981; Girod et al. 1981). The diopsides surrounded by olivines tend to have higher $\mathrm{Al}_{2} \mathrm{O}_{3}$ and $\mathrm{Cr}_{2} \mathrm{O}_{3}$ contents.

The $\mathrm{Mg} /(\mathrm{Mg}+\mathrm{Fe})$ ratios have a very limited range $(0.928-0.934)$ and are higher than those of coexisting olivines $(0.098-0.914)$. In contrast with the very good correlation in $\mathrm{Fe} / \mathrm{Mg}$ (Fig. $7 \mathrm{a}$ ), the correlations of $\mathrm{Ca} / \mathrm{Mg}$ and $\mathrm{Al}$ (Fig. $7 \mathrm{~b}, \mathrm{c}$ ) show considerable variations in partition coefficients, suggesting a more effi-

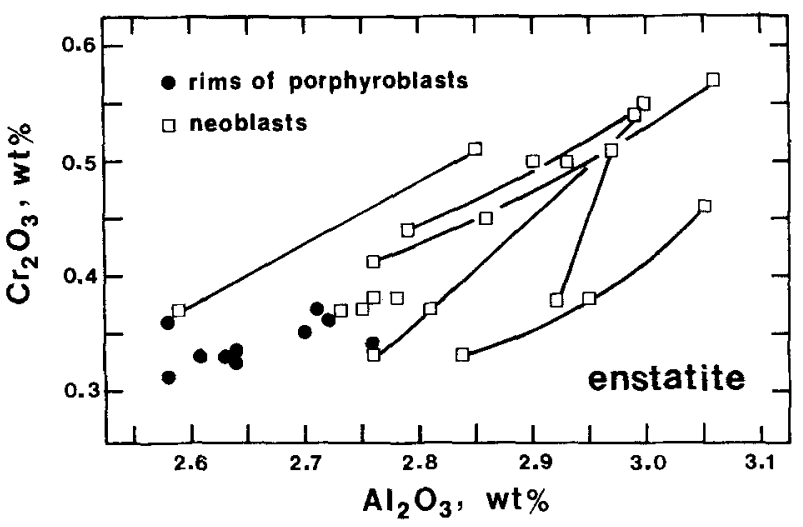

Fig. 5. Correlation between $\mathrm{Cr}_{2} \mathrm{O}_{3}$ and $\mathrm{Al}_{2} \mathrm{O}_{3}$ in enstatite crystals. Point analyses from a single grain are connected by a solid line

Table 5. Representative microprobe analyses of diopside crystals. Columns 1-4: those closely associated with spinels; columns 5 and 6: those completely surrounded by olivine crystals

\begin{tabular}{|c|c|c|c|c|c|c|}
\hline Sample No. & $\mathrm{A} 2$ & A3 & $\mathrm{B} 2$ & $\mathrm{C} 1$ & A 6 & B3 \\
\hline $\mathrm{SiO}_{2}$ & 53.11 & 53.46 & 53.69 & 53.32 & 52.92 & 53.22 \\
\hline $\mathrm{TiO}_{2}$ & 0.30 & 0.35 & 0.37 & 0.34 & 0.45 & 0.41 \\
\hline $\mathrm{Al}_{2} \mathrm{O}_{3}$ & 4.35 & 4.31 & 4.26 & 4.08 & 4.49 & 4.37 \\
\hline $\mathrm{Cr}_{2} \mathrm{O}_{3}$ & 1.09 & 1.17 & 1.06 & 0.94 & 1.25 & 1.23 \\
\hline $\mathrm{Fe}_{2} \mathrm{O}_{3}$ & 1.80 & 0.37 & 0.26 & 2.17 & 1.34 & 0.63 \\
\hline $\mathrm{FeO}$ & 0.46 & 1.75 & 1.82 & 0.13 & 0.76 & 1.48 \\
\hline $\mathrm{MgO}$ & 16.27 & 15.86 & 16.01 & 16.44 & 15.88 & 16.09 \\
\hline $\mathrm{MnO}$ & 0.08 & 0.07 & 0.07 & 0.08 & 0.14 & 0.08 \\
\hline $\mathrm{CaO}$ & 21.42 & 21.18 & 20.92 & 21.83 & 21.40 & 21.07 \\
\hline $\mathrm{Na}_{2} \mathrm{O}$ & 1.46 & 1.51 & 1.52 & 1.43 & 1.54 & 1.49 \\
\hline Total & 100.34 & 100.03 & 99.98 & 100.76 & 100.17 & 100.07 \\
\hline $\mathrm{Si}$ & 1.907 & 1.928 & 1.937 & 1.909 & 1.907 & 1.919 \\
\hline $\mathrm{Al}^{\mathrm{IV}}$ & 0.093 & 0.072 & 0.063 & 0.091 & 0.093 & 0.081 \\
\hline $\mathrm{Al}^{\mathrm{VI}}$ & 0.095 & 0.111 & 0.118 & 0.082 & 0.099 & 0.105 \\
\hline $\mathrm{Ti}$ & 0.008 & 0.010 & 0.010 & 0.009 & 0.012 & 0.011 \\
\hline $\mathrm{Cr}$ & 0.035 & 0.037 & 0.034 & 0.030 & 0.040 & 0.040 \\
\hline $\mathrm{Fe}^{3+}$ & 0.049 & 0.010 & 0.007 & 0.060 & 0.036 & 0.017 \\
\hline $\mathrm{Fe}^{2+}$ & 0.014 & 0.053 & 0.055 & 0.004 & 0.023 & 0.045 \\
\hline $\mathrm{Mg}$ & 0.870 & 0.853 & 0.860 & 0.876 & 0.854 & 0.863 \\
\hline $\mathrm{Mn}$ & 0.003 & 0.002 & 0.002 & 0.003 & 0.004 & 0.002 \\
\hline $\mathrm{Ca}$ & 0.824 & 0.818 & 0.808 & 0.837 & 0.827 & 0.814 \\
\hline $\mathrm{Na}$ & 0.102 & 0.106 & 0.106 & 0.099 & 0.105 & 0.103 \\
\hline \multicolumn{7}{|l|}{ Molec.\% } \\
\hline $\mathrm{Mg}_{2} \mathrm{Si}_{2} \mathrm{O}_{6}$ & 48.07 & 46.61 & 47.02 & 48.24 & 47.21 & 47.49 \\
\hline $\mathrm{Ca}_{2} \mathrm{Si}_{2} \mathrm{O}_{6}$ & 40.83 & 41.31 & 41.01 & 41.57 & 41.18 & 40.61 \\
\hline $\mathrm{CaAl}_{2} \mathrm{SiO}_{6}$ & 4.25 & 2.84 & 2.62 & 4.02 & 3.87 & 3.22 \\
\hline $\mathrm{NaFeSi}_{2} \mathrm{O}_{6}$ & 2.71 & 0.55 & 0.38 & 3.30 & 1.99 & 0.93 \\
\hline $\mathrm{NaCrSi}_{2} \mathrm{O}_{6}$ & 1.94 & 2.02 & 1.86 & 1.65 & 2.21 & 2.18 \\
\hline $\mathrm{Fe}_{2} \mathrm{Si}_{2} \mathrm{O}_{6}$ & 0.77 & 2.90 & 3.01 & 0.22 & 1.27 & 2.46 \\
\hline $\mathrm{NaAlSi}_{2} \mathrm{O}_{6}$ & 0.99 & 3.22 & 3.55 & 0.50 & 1.61 & 2.51 \\
\hline $\mathrm{CaTiAl}_{2} \mathrm{O}_{6}$ & 0.44 & 0.55 & 0.55 & 0.50 & 0.66 & 0.60 \\
\hline
\end{tabular}

cient exchange of $\mathrm{Mg}$ and $\mathrm{Fe}$ than $\mathrm{Ca}$ and $\mathrm{Al}$ between diopside and enstatite neoblasts.

\section{Spinel}

Only the vermicular spinels (e.g., Fig. $3 b$-d) were analyzed. The ferric iron was calculated by assuming that the spinels represent solid solution between $\mathrm{R}^{2+} \mathrm{R}_{2}^{3+} \mathrm{O}_{4}$ and $\mathrm{R}_{2}^{2+} \mathrm{R}^{4+} \mathrm{O}_{4}$. The molecular proportions (in mole \%) were calculated after allocating $\mathrm{Mn}$ to $\mathrm{Fe}$ and $\mathrm{Ni}$ to $\mathrm{Mg}$. 


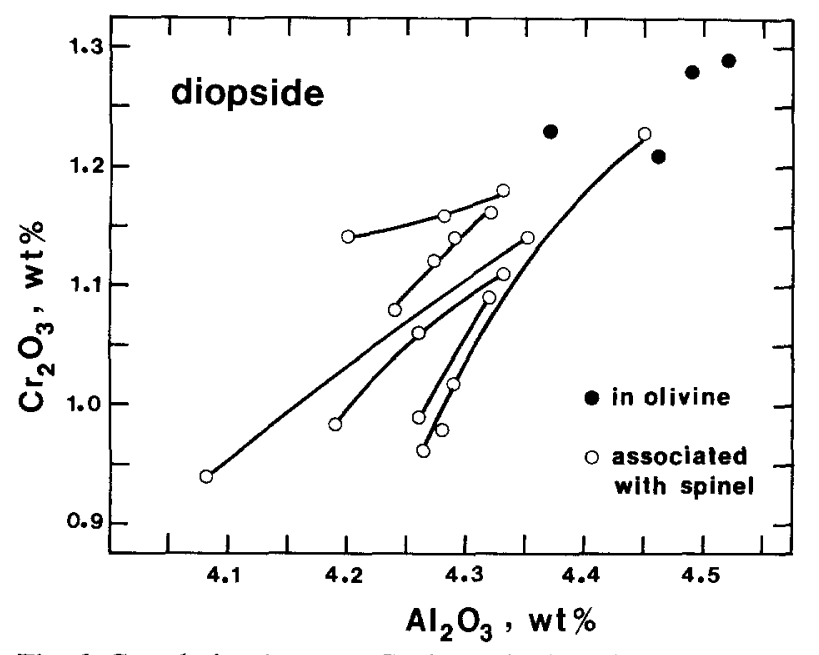

Fig. 6. Correlation between $\mathrm{Cr}_{2} \mathrm{O}_{3}$ and $\mathrm{Al}_{2} \mathrm{O}_{3}$ in diopside crystals. Each solid line connects the point analyses from a grain
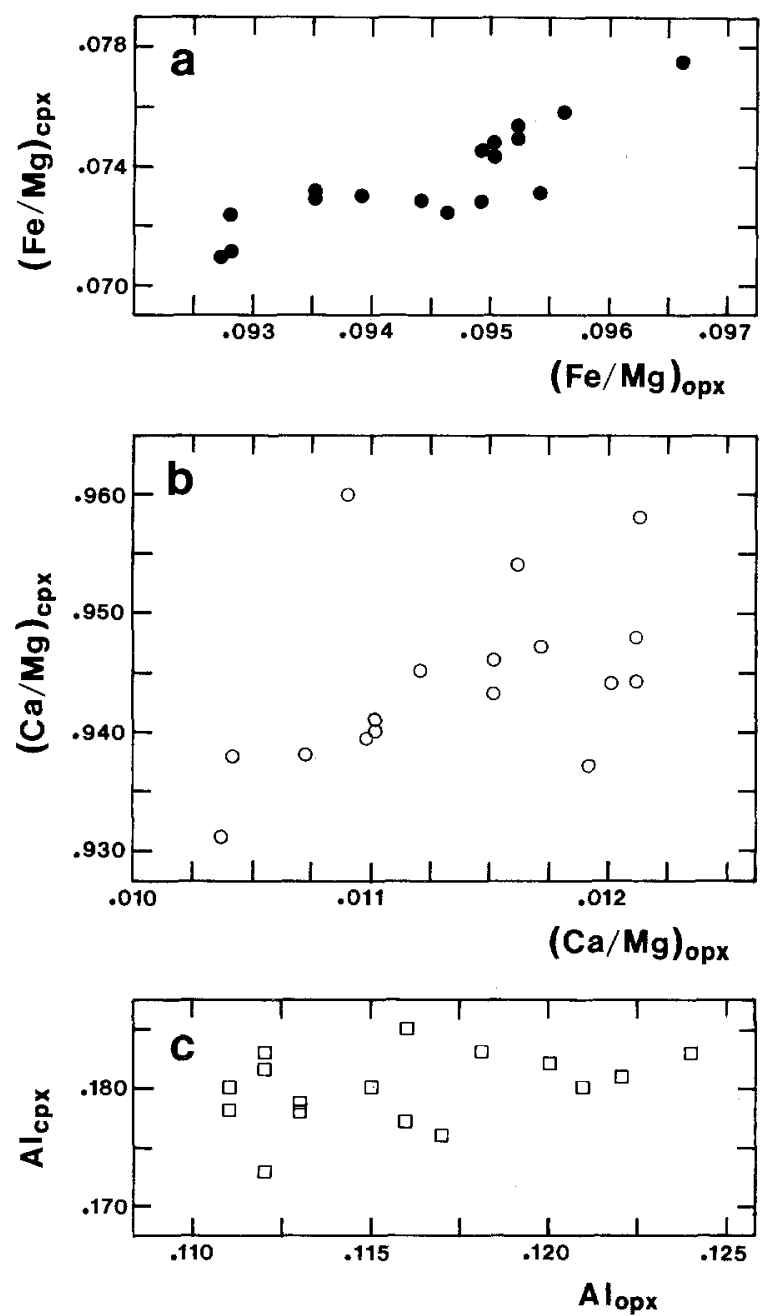

Fig. 7a-c. Plots of a $\mathrm{Fe} / \mathrm{Mg}, \mathbf{b ~ C a} / \mathrm{Mg}$, and $\mathbf{c} \mathrm{Al}$ values in coexisting diopside and enstatite neoblasts

Regardless of the variations in spinel compositions, analyses obtained in a given grain indicate that the zoning is beyond the limit of microprobe resolution. In all cases, spinel and chromite make up over $95 \%$ of all components, with only minor magnesiochromite, ulvospinel, and magnetite components. The $\mathrm{Al} / \mathrm{Cr} \mathrm{ra}-$
Table 6. Representative microprobe analyses of spinel grains. Each composition is obtained by averaging 3 to 5 individual analyses in that grain

\begin{tabular}{|c|c|c|c|c|c|c|}
\hline Sample no. & A 2 & A 3 & B1 & B2 & $\mathrm{C} 1$ & $\mathrm{C} 2$ \\
\hline $\mathrm{SiO}_{2}$ & 0.14 & 0.14 & 0.07 & 0.09 & 0.06 & 0.05 \\
\hline $\mathrm{TiO}_{2}$ & 0.16 & 0.17 & 0.15 & 0.14 & 0.16 & 0.17 \\
\hline $\mathrm{Al}_{2} \mathrm{O}_{3}$ & 46.09 & 47.39 & 47.31 & 47.60 & 46.78 & 46.85 \\
\hline $\mathrm{Cr}_{2} \mathrm{O}_{3}$ & 21.14 & 20.38 & 20.89 & 21.08 & 22.54 & 21.95 \\
\hline $\mathrm{Fe}_{2} \mathrm{O}_{3}$ & 1.17 & 0.10 & 0.10 & 1.16 & 0.00 & 0.30 \\
\hline $\mathrm{FeO}$ & 11.26 & 11.43 & 11.17 & 11.08 & 11.11 & 12.04 \\
\hline $\mathrm{MgO}$ & 19.03 & 19.02 & 19.30 & 19.13 & 18.27 & 18.21 \\
\hline $\mathrm{MnO}$ & 0.09 & 0.11 & 0.09 & 0.11 & 0.10 & 0.11 \\
\hline $\mathrm{NiO}$ & 0.42 & 0.46 & 0.49 & 0.44 & 0.45 & 0.48 \\
\hline Total & 99.50 & 99.20 & 99.57 & 100.83 & 99.47 & 100.16 \\
\hline $\mathrm{Si}$ & 0.003 & 0.003 & 0.002 & 0.002 & 0.002 & 0.001 \\
\hline Ti & 0.003 & 0.003 & 0.003 & 0.003 & 0.003 & 0.003 \\
\hline $\mathrm{Al}$ & 1.450 & 1.478 & 1.474 & 1.477 & 1.464 & 1.472 \\
\hline $\mathrm{Cr}$ & 0.521 & 0.508 & 0.514 & 0.490 & 0.532 & 0.514 \\
\hline $\mathrm{Fe}^{3+}$ & 0.017 & 0.002 & 0.002 & 0.023 & 0.000 & 0.006 \\
\hline $\mathrm{Fe}^{2+}$ & 0.254 & 0.253 & 0.247 & 0.242 & 0.248 & 0.252 \\
\hline $\mathrm{Mg}$ & 0.741 & 0.741 & 0.746 & 0.751 & 0.739 & 0.740 \\
\hline $\mathrm{Mn}$ & 0.002 & 0.002 & 0.002 & 0.003 & 0.002 & 0.002 \\
\hline $\mathrm{Ni}$ & 0.009 & 0.010 & 0.010 & 0.009 & 0.010 & 0.010 \\
\hline \multicolumn{7}{|l|}{ Molec. $\%$} \\
\hline $\mathrm{MgAl}_{2} \mathrm{O}_{4}$ & 72.65 & 74.12 & 73.85 & 73.97 & 73.27 & 73.67 \\
\hline $\mathrm{MgCr}_{2} \mathrm{O}_{4}$ & 2.51 & 1.21 & 1.90 & 2.10 & 0.70 & 1.40 \\
\hline $\mathrm{FeCr}_{2} \mathrm{O}_{4}$ & 23.64 & 24.27 & 23.85 & 22.43 & 25.93 & 24.33 \\
\hline $\mathrm{Fe}_{2} \mathrm{TiO}_{4}$ & 0.30 & 0.30 & 0.30 & 0.30 & 0.10 & 0.30 \\
\hline $\mathrm{Fe}_{3} \mathrm{O}_{4}$ & 0.90 & 0.10 & 0.10 & 1.20 & - & 0.30 \\
\hline
\end{tabular}

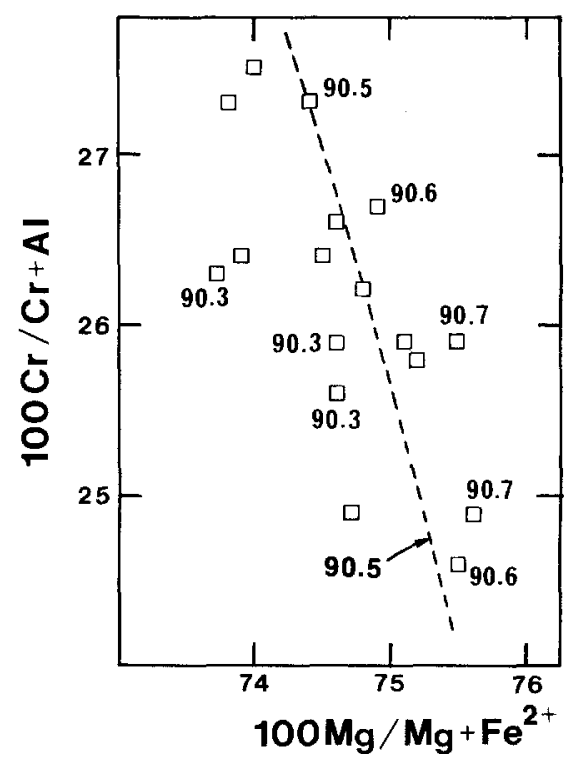

Fig. 8. Correlation between $\mathrm{Cr} /(\mathrm{Cr}+\mathrm{Al})$ and $\mathrm{Mg} /\left(\mathrm{Mg}+\mathrm{Fe}^{2+}\right)$ in spinel neoblasts. The Fo contents of the coexisting olivines are given by the numbers beside the points

tios have a range of 2.8-3.1, typical for xenoliths from alkali basalts (Basu and MacGregor 1975; Carswell 1980). The Fo contents in the coexisting olivines vary more consistently with $\mathrm{Mg} /\left(\mathrm{Mg}+\mathrm{Fe}^{2+}\right)$ than $\mathrm{Cr} /(\mathrm{Cr}+\mathrm{Al})$ in spinels, indicating a more concordant $\mathrm{Fe} / \mathrm{Mg}$ partitioning between these two phases (Fig. 8; Irvine 1965). The 


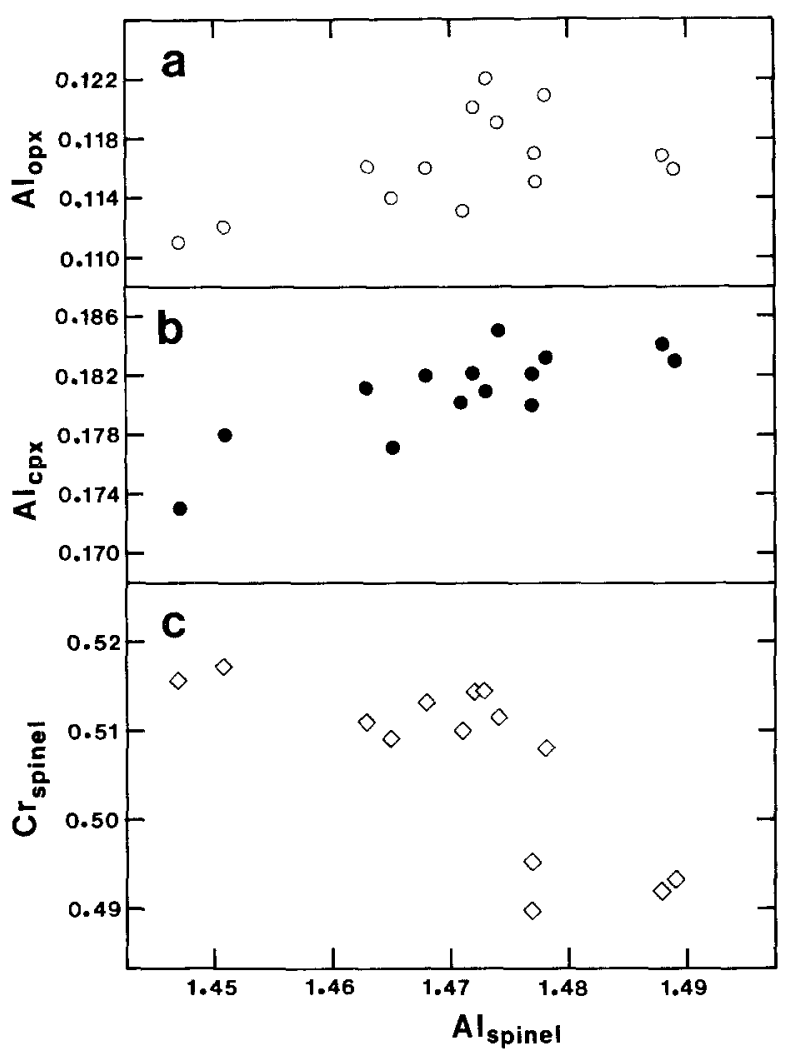

Fig. 9. Plots of a $\mathrm{Al}$ in enstatite, $\mathbf{b} \mathrm{Al}$ in diopside, and $\mathbf{c} \mathrm{Cr}$ in spinel versus $\mathrm{Al}$ in spinel

correlations of $\mathrm{Al}$ contents between coexisting spinel and pyroxenes are presented in Fig. 9a, b, and the correlation between $\mathrm{Al}$ and $\mathrm{Cr}$ in spinels is shown in Fig. $9 \mathrm{c}$.

\section{Interstitial glass}

The compositions of interstitial glasses are relatively homogeneous and are characterized by the high $\mathrm{SiO}_{2}(55.8-58.7 \mathrm{wt} \%), \mathrm{Na}_{2} \mathrm{O}$ (6.4-7.6 wt\%), and $\mathrm{Al}_{2} \mathrm{O}_{3}(20.0-21.6 \mathrm{wt} \%)$ contents, high $\mathrm{Na} /$ $(\mathrm{Na}+\mathrm{K})$ ratios $(0.90-0.93)$, and low $\mathrm{Mg} /(\mathrm{Mg}+\mathrm{Fe})$ ratios $(0.74-0.60)$ (Table 7). The totals of 99.8 to $100.9 \mathrm{wt} \%$ indicate that these glasses contain little dissolved volatiles. The norms range from nepheline- to slightly quartz-normative, with two of them containing neither quartz nor nepheline but both olivine and enstatite. Based on the $\left(\mathrm{Na}_{2} \mathrm{O}+\mathrm{K}_{2} \mathrm{O}\right)$ versus $\mathrm{SiO}_{2}$ contents, these compositions are similar to trachyandesite, but the total $\mathrm{FeO}$ is too low and $\mathrm{Al}_{2} \mathrm{O}_{3}$ and $\mathrm{CaO}$ are too high (Cox et al. 1979).

In a $\mathrm{Na}-\mathrm{Ca}-\mathrm{K}$ plot (Fig. 10), these glass compositions show a trend defined by the slight increase of $\mathrm{K}$ with increasing $\mathrm{Na} / \mathrm{Ca}$, similar to the glasses in the lherzolites from Victorian basanites (Frey and Green 1974). In particular, a few glasses in internal veins associated with olivine and spinel in their lherzolites are chemically almost identical to these glasses. Most of the glasses in ultramafic xenoliths from alkali basalts have lower $\mathrm{Na} / \mathrm{Ca}$ and higher K values (e.g., Forbes and Starmer 1974; Irving 1974; Ellis 1976; Francis 1976; MacRae 1979; Girod et al. 1981; Jones et al. 1983). The only exceptions are the two analyses (inverted triangles, Fig. 10) of glasses resulting from melting of low-K amphiboles (Frey and Green 1974). Partial melts experimentally generated at 15 and $20 \mathrm{~kb}$ under hydrous conditions by Mysen and Boettcher (1975) have higher $\mathrm{Ca}$, lower $\mathrm{Na}$ and $\mathrm{K}$ contents than our glasses, whereas those by Nicholls (1974) have slightly higher K contents than, but similar $\mathrm{Na} / \mathrm{Ca}$ ratios to, our glasses. It is important to note that further comparisons may be hampered by the possibility that other published data my have erroneously low $\mathrm{Na}$.
Table 7. Selected microprobe analyses and corresponding norms of interstitial glasses. Sample designation: capital letters refer to thin sections; each number indicates a glass veinlet within that thin section

\begin{tabular}{lrrrrrrr}
\hline Sample no. & $\mathrm{A} 1 \mathrm{a}$ & $\mathrm{A} 1 \mathrm{~b}$ & \multicolumn{1}{c}{$\mathrm{A} 2$} & \multicolumn{1}{c}{$\mathrm{A} 3$} & $\mathrm{C} 1$ & $\mathrm{C} 2$ & $\mathrm{C} 3$ \\
\hline $\mathrm{SiO}_{2}$ & 56.61 & 56.03 & 55.87 & 58.70 & 56.89 & 58.03 & 58.37 \\
$\mathrm{TiO}_{2}$ & 1.32 & 1.37 & 1.37 & 1.43 & 1.20 & 1.24 & 1.38 \\
$\mathrm{Al}_{2} \mathrm{O}_{3}$ & 21.37 & 21.54 & 21.21 & 20.86 & 20.33 & 20.02 & 20.28 \\
$\mathrm{Fe}_{2} \mathrm{O}_{3}$ & 0.22 & 0.25 & 0.29 & 0.27 & 0.26 & 0.26 & 0.27 \\
$\mathrm{FeO}$ & 1.86 & 2.11 & 2.39 & 2.38 & 2.37 & 2.23 & 2.28 \\
$\mathrm{MgO}$ & 3.03 & 3.13 & 2.50 & 2.21 & 2.50 & 2.62 & 2.62 \\
$\mathrm{MnO}$ & 0.03 & 0.11 & 0.00 & 0.00 & 0.08 & 0.03 & 0.04 \\
$\mathrm{CaO}$ & 6.75 & 6.62 & 7.86 & 6.75 & 7.66 & 7.32 & 7.51 \\
$\mathrm{BaO}$ & 0.34 & 0.10 & 0.15 & 0.23 & 0.15 & 0.23 & 0.37 \\
$\mathrm{Na}_{2} \mathrm{O}$ & 7.31 & 7.55 & 7.28 & 6.68 & 7.03 & 6.46 & 6.44 \\
$\mathrm{~K}_{2} \mathrm{O}$ & 1.08 & 1.08 & 0.97 & 1.00 & 1.14 & 0.89 & 0.79 \\
$\mathrm{~F}$ & 0.30 & 0.14 & 0.16 & 0.12 & 0.27 & 0.12 & 0.14 \\
$\mathrm{P}_{2} \mathrm{O}_{5}$ & 0.48 & 0.32 & 0.46 & 0.24 & 0.27 & 0.38 & 0.24 \\
\hline Total & 100.70 & 100.35 & 100.51 & 100.87 & 100.15 & 99.83 & 100.73
\end{tabular}

\begin{tabular}{lrrrrrrr} 
CIPW wt \% norm & $\left(\mathrm{Fe}^{3+} / \mathrm{Fe}^{2+}=0.1\right)$ \\
qz & - & - & - & - & - & 0.05 & 0.31 \\
or & 6.36 & 6.37 & 5.71 & 5.86 & 6.74 & 5.27 & 4.64 \\
ab & 52.14 & 48.92 & 47.58 & 56.18 & 50.36 & 54.89 & 54.27 \\
an & 22.23 & 21.64 & 22.26 & 23.84 & 20.57 & 23.11 & 24.00 \\
ne & 5.16 & 8.04 & 7.48 & - & 4.98 & - & - \\
di & 4.73 & 5.65 & 8.24 & 4.73 & 8.61 & 6.80 & 7.33 \\
hd & 0.60 & 1.02 & 2.17 & 1.33 & 2.77 & 1.71 & 1.72 \\
en & - & - & - & 3.02 & - & 3.40 & 3.10 \\
fs & - & - & - & 0.97 & - & 0.97 & 0.83 \\
fo & 3.73 & 3.61 & 1.67 & 0.17 & 1.56 & - & - \\
fa & 0.60 & 0.82 & 0.56 & 0.06 & 0.64 & - & - \\
mt & 0.31 & 0.36 & 0.42 & 0.39 & 0.37 & 0.37 & 0.39 \\
ilm & 2.49 & 2.60 & 2.59 & 2.69 & 2.27 & 2.36 & 2.61 \\
ap & 1.13 & 0.75 & 1.08 & 0.56 & 0.63 & 0.90 & 0.56 \\
fl & 0.52 & 0.22 & 0.24 & 0.20 & 0.50 & 0.17 & 0.24 \\
\hline
\end{tabular}

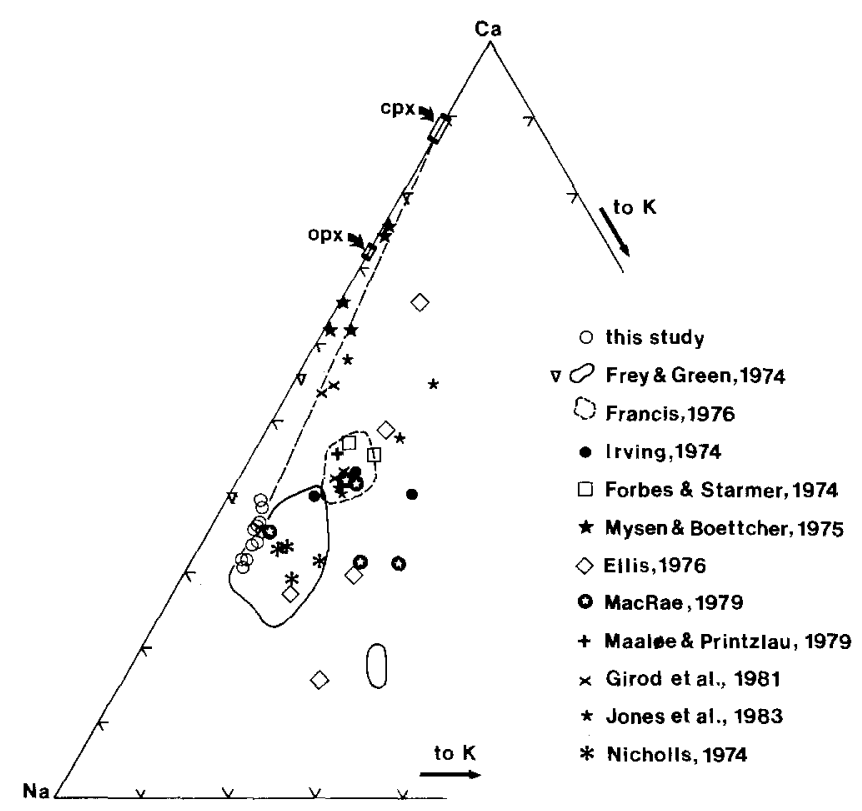

Fig. 10. A $\mathrm{Ca}-\mathrm{Na}-\mathrm{K}$ plot showing compositions of glasses in upper-mantle derived xenoliths and from experimentally generated melts. Typical upper mantle enstatites (opx) and diopsides (cpx) are also plotted. The trend of glass compositions in this study is indicated by the broken line 


\section{Temperature and pressure estimates}

One of the major purposes of studying ultramafic xenoliths is to investigate the temperature-pressure conditions they have experienced. Quantitative assessment of these conditions can be made based on the mineral chemistries with geothermometers and geobarometers derived from experiments and/or natural rocks. These schemes of temperaturepressure estimation are invariably based on the assumption of attainment of equilibrium among coexisting phases. In the present case, the imprint of chemical disequilibrium may be used to evaluate the temperature-pressure histories of these xenoliths (hereafter HAK xenoliths).

\section{Geothermometry}

Geothermometers pertaining to spinel peridotite assemblages include single-pyroxene, two-pyroxene, olivine-spinel, and three-phase thermometers. The single-pyroxene thermometer of Herzberg (1978), the two-pyroxene thermometers of Mysen (1976) and Lindsley (1983), the olivinespinel thermometer of Engi (1983), and the ol-opx-sp thermometer of Sachtleben and Seck (1981) were selected for temperature examination of HAK xenoliths. Pairs of individual analyses of coexisting neoblastic phases are used, whenever applicable, to obtain a maximum temperature range for each thermometer. Typically about fifteen temperatures were calculated for each pyroxene thermometer and about ten for each thermometer involving spinel. The results (Table 8) show that the temperature ranges calculated from $\mathrm{Al}$ contents are consistently higher than those from $\mathrm{Mg}-\mathrm{Fe}$ partitioning.

Donaldson (1978) attributed the discrepancy in temperatures derived from single- and two-pyroxene methods of Mysen (1976) to the possible errors in estimating $\mathrm{Al}^{\mathrm{VI}}$ contents in pyroxenes. In this study, the application of cationnormalization scheme results in lower $\mathrm{Al}^{\mathrm{VI}}$ contents for enstatites, while those for diopsides are nearly unaffected. As a result, a higher temperature range is obtained from the two-pyroxene method of Mysen, which agrees very well with the temperatures obtained from single-pyroxene methods of Herzberg (1978) (Table 8) and Mysen (1976). Thus, although its effects on temperature estimation of xenoliths deserve further studies, the cation-normalization appears to give better estimation of $\mathrm{Al}^{\mathrm{VI}}$ contents in enstatites.

The lower temperature range obtained from the method of Lindsley (1983) (Table 8) is due mainly to exsolution of diopsides from enstatites (Fig. 3b-d). The twopyroxene thermometer of Wells (1977) gives a very similar temperature range $\left(850^{\circ}-930^{\circ} \mathrm{C}\right)$. Because such exchanges are strongly temperature dependent, the lower temperature range from Lindsley's method indicates a more effective reequilibration of $\mathrm{Mg}$ and $\mathrm{Fe}$ relative to $\mathrm{Al}$ in response to temperature decrease.

Thermometers involving spinel require more careful calibration due not only to different kinetics of reequilibration of components between silicates and spinel but to the effects of $\mathrm{C} r$ contents in the coexisting spinels and enstatites (e.g., Fujii and Scarfe 1982; Ghent et al. 1980; Henry and Medaris 1980; Donaldson 1978). An experimentally derived olivine-spinel thermometer (Engi 1983) and a thermometer calibrated using natural peridotites with well-established chemical equilibrium (Sachtleben and Seck 1981) give essentially identical temperature ranges of $800^{\circ}-900^{\circ} \mathrm{C}$ (Table 8) for HAK samples.
Table 8. Temperature ranges for the sample HAK-1 obtained from five geothermometers

\begin{tabular}{|c|c|c|}
\hline Thermometer & Method & $\mathrm{T}\left({ }^{\circ} \mathrm{C}\right)$ \\
\hline Herzberg (1978) & $\begin{array}{l}\mathrm{X}_{\mathrm{CaAl}_{2} \mathrm{SiO}_{6}}^{\mathrm{cpx}}=\left(\mathrm{X}_{\mathrm{Ca}}^{\mathrm{M} 2}\right)\left(\mathrm{X}_{\mathrm{Al}}^{\mathrm{M} 1}\right), \\
\text { experimentally calibrated } \\
\text { in CMAS system }\end{array}$ & $910-1,030$ \\
\hline Mysen (1976) & $\begin{array}{l}\text { Partitioning of }\left(\mathrm{Al}^{\mathrm{vI}} / \mathrm{Cr}\right) \\
\text { between opx and } \mathrm{cpx}, \\
\text { calibrated using natural } \\
\text { peridotites }\end{array}$ & $900-1,040$ \\
\hline Lindsley (1983) & $\begin{array}{l}\text { Experimentally determined } \\
\text { opx-cpx solvus projected } \\
\text { to En-Fs - Wo plane at } 15 \mathrm{~kb}\end{array}$ & $850-900$ \\
\hline Engi (1983) & $\begin{array}{l}\text { Experimentally determined } \\
\mathrm{Mg}-\mathrm{Fe} \text { exchange between ol } \\
\text { and sp with correction to } \\
20 \mathrm{~kb}\end{array}$ & $820-880$ \\
\hline $\begin{array}{l}\text { Sachtleben and } \\
\text { Seck (1981) }\end{array}$ & $\begin{array}{l}\text { Solubility of } \mathrm{A} 1 \text { in opx } \\
\text { equilibrated with o1 }+\mathrm{sp} \text {, } \\
\text { calibrated using natural } \\
\text { spinel peridotites }\end{array}$ & $840-910$ \\
\hline
\end{tabular}

In summary, it is proposed that for the HAK samples, the reequilibration of components started at temperatures higher than $1,050^{\circ} \mathrm{C}$ and reached a lower limit of about $800^{\circ} \mathrm{C}$.

\section{Geobarometry}

The phase boundaries defining the stability field of spinel peridotite in temperature-pressure space are commonly used for pressure estimation. We choose three versions of this phase relationship and read a maximum pressure range at the temperature interval of $800^{\circ}$ to $1,050^{\circ} \mathrm{C}$ from each of them. The ranges are 7 to $17 \mathrm{~kb}$ (O'Hara et al. 1971; Herzberg 1978) and 5 to $14 \mathrm{~kb}$ (Obata 1976).

Several experimental studies on garnet-spinel transition in MAS and CMAS systems give the upper limits of spinel stability as a function of temperature. The values at $1,050^{\circ} \mathrm{C}$ are: $18.5 \mathrm{~kb}$ (O'Neill 1981) and $16 \mathrm{~kb}$ (Jenkins and Newton 1979). It has been shown, however, that the extent of spinel stability is also dependent on the compositions of spinel (O'Neill 1981; Wood 1978) and olivine (Jenkins and Newton 1979).

The single-pyroxene barometers of Mercier (1980), which are based on the empirical formulation using phase chemistries taking into account the effect of $\mathrm{Cr}$ on $\mathrm{Al}$ solubility in pyroxenes, yield pressure ranges of $15.5-18.5 \mathrm{~kb}$ for enstatites, and $14-18 \mathrm{~kb}$ for diopsides. We suggest, therefore, that HAK xenoliths were last equilibrated at $1518 \mathrm{~kb}$ before being incorporated into the ascending host magma.

\section{Origin of interstitial glasses}

Interstitial glasses are commonly suggested to be produced by decompressional melting of the xenoliths during ascent. This interpretation has recently been questioned by Maaløe and Printzlau (1979) based on the rare occurrence of such glasses in upper-mantle derived xenoliths. Experimental (Millhollen et al. 1974; Scarfe et al. 1979) and petrologic (Maaløe and Printzlau 1979) evidence indicates that at high 
pressures, especially for small degrees of partial melting, the initial melts typically occur as isolated blebs or thin patches between crystals and are closely associated with partially resorbed spinels and diopsides. Even though the melt may migrate into the grain boundaries and fractures in response to pressure decrease upon ascent, the resorbed spinel and diopside grains should be preserved. This feature, however, is absent in HAK xenoliths. White (1966) and Carswell (1975) suggested that during ascent, jadeitic diopsides may decompose to produce secondary amphibole and mica or high $\mathrm{Na}-\mathrm{Al}$ melts. Donaldson (1978) interpreted the spongy-textured diopside in some Calton Hill xenoliths as the result of incongruent melting of the formerly sodic diopside. Partially dissolved diopside is also absent in HAK xenoliths. Thus, HAK interstitial glasses cannot be produced from the existing phases by decompressional melting, and it is very likely that they formed before the development of spinel neoblasts.

It is also frequently proposed that interstitial glasses result from the breakdown of kaersutitic or pargasitic amphiboles (e.g., Forbes and Starmer 1974; Frey and Green 1974; Francis 1976; Girod et al. 1981). These amphiboles may form in the upper mantle by reaction of $\mathrm{Na}$ - or $\mathrm{K}$-rich metasomatic fluids with garnet- or spinel-peridotite assemblage (e.g., Boyd 1971; Francis 1976). Stewart et al. (1979) showed experimentally that pargasite reacts to form olivine plus diopside plus liquid at temperatures higher than about $1,025^{\circ} \mathrm{C}$, which may occur during the ascent of host basalt magma. We chose an appropriate amphibole composition from Francis (1976) and used our averaged mineral and glass compositions to formulate a reaction

1 amphibole $=0.26$ olivine +0.28 diopside +0.38 glass

with a total residue (the summation of misfit in each component after regression) of $5.30 \mathrm{wt} \%$. This reaction indicates that about $1.8 \mathrm{wt} \%$ amphibole is required to produce $0.70 \mathrm{wt} \%$ glass (see Table 2 ). Petrographically, however, it is difficult to envisage the preexistence of such a large amount of amphibole in HAK xenoliths. The lack of complex reaction features around spinel, as described by Francis (1976), rules out the formation of amphibole from spinel, which can be confirmed by the normal chemistries of diopside neoblasts in contact with spinel grains. Francis (1976) found that in Nunivak Island xenoliths, diopsides in amphibole- or glass-bearing lherzolites are distinctly jadeitic ( $\mathrm{Al}^{\mathrm{VI}}$ / $\mathrm{Al}^{\mathrm{rV}}$ no less than 2).

Jones et al. (1983) and Maaløe and Printzlau (1979) suggested that the glasses in lherzolites from Olmani (Tanzania) and Dreiser Weiher (FRG) represent partial melts generated under upper mantle conditions. The premise for this interpretation is that the glass must be in equilibrium with the host mineral assemblage. The data on the mole fractions of $\mathrm{Mg}$ and $\mathrm{Fe}$ in the HAK glasses fall in a well defined linear trend, with the most magnesian glass showing potential equilibrium with olivine of $\mathrm{Fo}_{91}$ composition at about $990^{\circ} \mathrm{C}$ (Fig. 11). Note that this trend passes through the point representative of upper mantle diopside (21.5 $\mathrm{mol} \% \mathrm{MgO}, 0.8 \mathrm{~mol} \% \mathrm{FeO}$, this study), indicating some chemical control of these glasses by diopside, which is also shown by the chemical trend in the $\mathrm{Na}-\mathrm{Ca}-\mathrm{K}$ plot (Fig. 10, broken line). By applying the lever rule to Fig. 11, a reaction

1 melt $=0.9$ glass +0.1 diopside

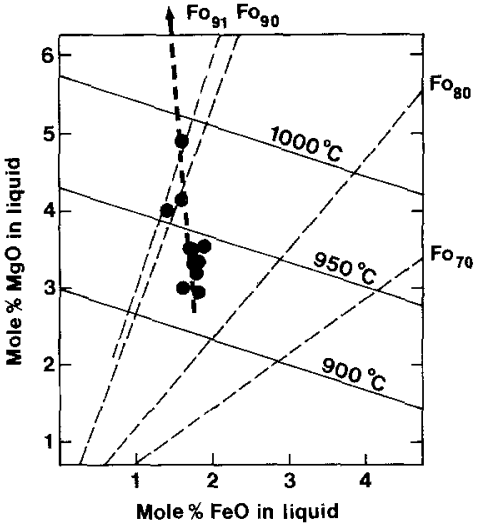

Fig. 11. HAK glass data (solid circles, calculated by assuming $\mathrm{Fe}^{+3} / \mathrm{Fe}^{+2}=0.1$ ) plotted in a grid (Fig. 7 of Roeder and Emslie 1970) showing olivine-liquid equilibrium. Broken and solid lines indicate olivine isopleths and temperatures, respectively. The trend defined by the HAK glass compositions, shown by the heavy, dashed line, heads toward the $\mathrm{Mg}-\mathrm{Fe}$ concentration for a typical upper mantle diopside. See text for interpretation

can be established, where the melt represents the liquid in equilibrium with $\mathrm{FO}_{91}$ at around $1,000^{\circ} \mathrm{C}$, and the glass represents the averaged composition of HAK glasses. We thus suggest that the HAK glass was generated by partial melting within the upper mantle at temperatures higher than about $1,000^{\circ} \mathrm{C}$, followed by crystallization of, on average, $10 \mathrm{vol} \%$ diopside at lower temperatures.

In comparing the calculated equilibrium HAK melt composition with some natural and synthetic melts with similar chemistries (Table 9), it appears that most of the natural melts (DWG, HAA, NBV) have lower Mg and thus lower $\mathrm{Mg} /(\mathrm{Mg}+\mathrm{Fe})$ values. This indicates, in addition to different upper mantle chemistry and conditions of partial melting ( $T$, P, fluid chemistry), some degree of differentiation of these melts after their generation. The high $\mathrm{K}$ content in NIA glass is attributed to upper-mantle metasomatism with a relatively K-rich fluid (Francis 1976). A glass of similar origin (HAA, Girod et al. 1981) has very low $\mathrm{K}$ content, probably indicating a different metasomatic fluid chemistry. The chemistry of HAK melt is also comparable to that of experimentally produced partial melts (Nicholls 1974). It should be noted, however, that the water contents in experimental melts are generally high and not quantified. Unless the melt chemistry can be proved to be insensitive to fluid abundance under otherwise identical conditions, it is difficult to draw conclusions based on such comparisons.

The high Si and $\mathrm{Al}$ with low Mg contents in HAK glass indicates partial melting with the presence of fluid (e.g., Nicholls 1974; Mysen and Boettcher 1975; cf. Jaques and Green 1980; Takahashi and Kushiro 1983), whereas the high analytical totals suggest the presence of only a small amount of volatile components. Tatsumi and Ishizaka (1982) suggested that if $\mathrm{K}$ - or Ti-rich phases were not precipitated during magmatic evolution, then the $\mathrm{K}_{2} \mathrm{O} / \mathrm{TiO}_{2}$ ratio in a upper mantle-derived magma can be related to its water content because $\mathrm{K}$ is more soluble in water than Ti. They found that the $\mathrm{K}_{2} \mathrm{O} / \mathrm{TiO}_{2}$ ratios in a suite of high$\mathrm{Mg}$ andesites from Setouchi volcanic belt (Japan) have a range of 2-6, with the water contents of $1.0-1.9 \mathrm{wt} \%$. Midoceanic ridge basalts, which are essentially anhydrous, have 
Table 9. Calculated melt composition in equilibrium with the Saudi Arabian upper mantle (HAK) and its comparison with other melts with similar compositions

\begin{tabular}{lrrrrrrr}
\hline & HAK & DWG & HAA & NBV & NIA & N20 & N15 \\
\hline $\mathrm{SiO}_{2}$ & 57.02 & 53.19 & 57.36 & 53.42 & 58.99 & 57.7 & 55.9 \\
$\mathrm{TiO}_{2}$ & 1.23 & 0.27 & 0.60 & 2.94 & 0.16 & 0.4 & 0.4 \\
$\mathrm{Al}_{2} \mathrm{O}_{3}$ & 19.23 & 20.93 & 23.02 & 18.33 & 20.87 & 20.3 & 21.3 \\
$\Sigma \mathrm{FeO}$ & 2.46 & 3.93 & 2.89 & 6.71 & 2.77 & 4.1 & 4.1 \\
$\mathrm{MnO}$ & 0.05 & - & 0.01 & 0.11 & 0.07 & - & 0.2 \\
$\mathrm{MgO}$ & 4.02 & 3.58 & 1.83 & 2.66 & 3.60 & 4.7 & 5.2 \\
$\mathrm{CaO}$ & 8.64 & 8.86 & 9.48 & 6.82 & 6.58 & 5.4 & 5.8 \\
$\mathrm{Na}_{2} \mathrm{O}$ & 6.45 & 4.73 & 4.07 & 4.86 & 4.57 & 5.2 & 5.6 \\
$\mathrm{~K}_{2} \mathrm{O}$ & 0.90 & 1.74 & 0.61 & 2.65 & 2.10 & 2.2 & 1.4 \\
\hline $\mathrm{Total}$ & $100.00^{\mathrm{a}}$ & 97.23 & 99.87 & 98.50 & 99.71 & $100.0^{\mathrm{a}}$ & $99.9^{\mathrm{a}}$ \\
\hline \multicolumn{1}{c}{$\mathrm{Mg}$} & & & & & & & \\
$\mathrm{Mg}+\Sigma \mathrm{Fe}$ & 0.75 & 0.62 & 0.53 & 0.41 & 0.70 & 0.67 & 0.69 \\
\hline
\end{tabular}

HAK: Calculated liquid composition in equilibrium with a spinel harzburgite from Saudi Arabia (this study)

DWG : Composition of a glass bleb in a spinel lherzolite from Dreiser Weiher, Germany (Maaløe and Printzlau 1979)

HAA: Averaged composition of glasses in a lherzolite from southern Algeria (Girod et al. 1981)

NBV: Averaged composition of glasses in lherzolites from Newer Basalts, Victoria, Australia (MacRae 1979)

NIA: Composition of a glass from the fine-grained zone in a lherzolite from Nunivak Island, Alaska (Francis 1976)

N20, N15: Experimental liquid compositions in equilibrium with a peridotite at $1,000^{\circ} \mathrm{C}, 20$ and $15 \mathrm{~kb}$, respectively. Water saturated. (Nicholls 1974)

a normalized to $100 \mathrm{wt} \%$

$\mathrm{K}_{2} \mathrm{O} / \mathrm{TiO}_{2}$ ratios around 0.1 . The HAK melt (column 1 , Table 9) has a $\mathrm{K}_{2} \mathrm{O} / \mathrm{TiO}_{2}$ ratio of 0.73 , indicating that the water content is very likely to be of the order of several tenths of a percent. This range of water content is consistent with the analytical totals and is suggested to account for the chemical characteristics of the melt with the presence of diopside instead of amphibole on the liquidus.

Partial melting within the upper mantle involving Narich fluids could be invoked to explain the high $\mathrm{Na}$ content of the HAK glasses. Because of the extremely limited sample population, the source region of the partial melting cannot be specified.

\section{Discussion}

The HAK xenoliths exhibit the normal mineralogy of spinel peridotite xenoliths in alkali basalts (e.g., Varne 1977). Because of the much higher $\mathrm{Mg} /(\mathrm{Mg}+\mathrm{Fe})$ ratios in olivines, high $\mathrm{Cr}$ and low Ti contents in enstatites and much lower bulk $\mathrm{Na}$ and $\mathrm{Ti}$ contents, these xenoliths cannot represent the residual accumulates from the host basalt magma at depth. Because of the extremely low degree of partial melting and of the low temperatures recorded in the assemblages, they cannot be the source rock from which the alkali basalt magma was generated. Therefore, HAK samples join the growing number of ultramafic xenoliths with an accidental origin.

As discussed earlier, HAK xenoliths display features indicative of an incipient transition from protogranular to porphyroclastic texture. According to Mercier and Nicolas
(1975), for xenoliths that have undergone multiple cycles of deformation/recrystallization, the last two cycles may be texturally recognized. The key evidence for the completion of a cycle is the preservation of dispersed, rounded spinel grains inside the olivine grains or at triple grain junctions resulting from the post-deformation annealing. Because this type of spinel is absent in HAK samples, we conclude that they have been quenched in an intermediate state of deformation/recrystallization with preservation of primary textures. It follows that the diopsides completely surrounded by olivine grains (see Fig. 2) might represent the residuum from the initial partial melting because they were not exsolved from enstatites (see also Donaldson 1978). The neogenic diopsides occur either as exsolution lamellae within the enstatite hosts or has anhedral grains interstitial to exsolved spinel neoblasts.

The textures of neoblastic assemblages (Fig. $3 \mathrm{~b}-\mathrm{d}$ ) indicate subsolidus exsolution of spinel from the pyroxene host. In the CMAS system, this relationship can be described by the reaction

$$
2 \mathrm{Fo}+\mathrm{Ca}-\mathrm{Ts}+\mathrm{Mg}-\mathrm{Ts}=\mathrm{Di}+2 \mathrm{En}+2 \mathrm{Sp} \text {. }
$$

The presence of vermicular spinels associated with silicate phases indicates that the reaction proceeds to the right, which requires decreasing temperatures (Obata 1976; Varne 1977; Herzberg 1978). Varne (1977) noted the correlation between textures and temperatures of spinel lherzolites from Tasmania and suggested that the deformation/recrystallization cycle of Mercier and Nicolas (1975) proceeds with falling temperature. The textural transition in HAK xenoliths is consistent with this interpretation.

Based on the above argument, the exchange of components is among neoblastic phases represents the subsolidus reequilibration in response to temperature decrease. The different temperature ranges obtained in the present study are thus suggested to result from the different reequilibration rates of components. Fabries (1979) concluded a lower limit of exchange blocking of about $700^{\circ} \mathrm{C}$ in olivine-spinel assemblages. If so, then the $800^{\circ}-900^{\circ} \mathrm{C}$ range from olivinespinel thermometers can be explained in two ways: (1) it represents the steady-state temperature in the upper mantle and, therefore, the geotherm must pass through the point of about $800^{\circ} \mathrm{C}$ at $15-18 \mathrm{~kb}$; (2) the geotherm is less steep than suggested above, and the xenoliths were incorporated into the basalt magma before reaching the blocking temperature. The $800^{\circ}-900^{\circ} \mathrm{C}$ range thus represents the freeze-in temperatures. On the other hand, the $1,050^{\circ}-900^{\circ} \mathrm{C}$ range from pyroxene thermometers probably indicate a blocking temperature of about $900^{\circ} \mathrm{C}$ for $\mathrm{Ca} / \mathrm{Al}$ partitioning. The similar temperature ranges from two-pyroxene thermometers of Mysen (1976) and Herzberg (1978) might be indicative of an approach to a thermal steady-state (Fabries 1979). Thus, the alternative (1) is preferred. The evaluation of a detailed geotherm relies on further studies on xenoliths and on heat-flow data in this region.

The pressure range of $15-18 \mathrm{~kb}$ indicates the source region of HAK xenoliths of 50-60 km, which is in the upper mantle and above the low-velocity zone (LVZ) beneath the Arabian Shield since Miocene (Schmidt et al. 1982). Because HAK xenoliths are suggested to be upper-mantle fragments, the host basalt must have been generated and segregated deeper in the LVZ. According to the norm, the host basalt is classified as a basanite, which is most likely produced by about $2 \%$ partial melting of the upper mantle 


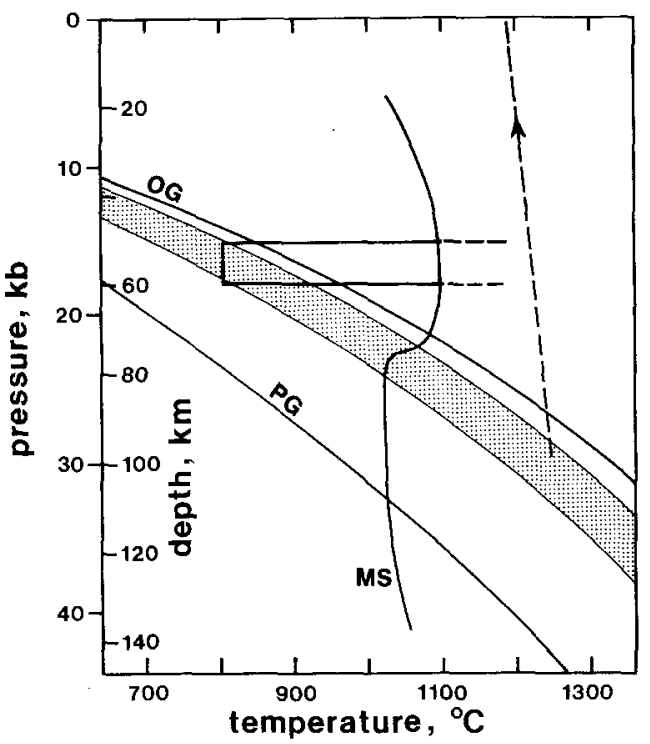

Fig. 12. A $P-T$ diagram illustrating the thermal conditions of the upper mantle beneath the Arabian Shield. The geotherm since Miocene, estimated from this study, is shown by the stippled zone. $P G$ Precambrian shield geotherm; $O G$ present oceanic geotherm (Clark and Ringwood 1964); MS wet mantle solidus (Eggler 1977). The horizontal bracket indicates the temperature range recorded by HAK xenoliths. The broken line represents the possible adiabatic path for the ascent of the xenolith-bearing alkali basalt magma

(e.g., Ringwood 1975). By assuming that this magma was segregated near the top of the LVZ (about $70 \mathrm{~km}$ deep, Schmidt et al. 1982), the depth of the source and the adiabatic path of ascent of this magma can be estimated (Ringwood 1975). Figure 12 summarizes the physical conditions of the upper mantle beneath the Arabian Shield deduced from this study. The supersolidus temperatures recorded by HAK xenoliths and inferred from the host basalt chemistry with respect to geotherm (stippled area in Fig. 12) at corresponding pressures suggests a two-stage magmatism in the upper mantle beneath the Arabian Shield since Miocene.

Acknowledgments. It is our pleasure to thank Abdulkader Afifi of this Department for drawing the xenolith locality to our attention and providing us with the two specimens. Thanks are due Dr. Erich Petersen and Mr. Guy Metz for their assistance with computer work, and Professor William Kelly, Mr. Andrew Schedl, and Abdulkader Afifi for helpful discussions. We are grateful to Drs. Richard Arculus, Finley Bishop, Robert Coleman, Bernard Evans, and an anonymous referee for their critical reviews of the manuscript.

\section{References}

Basu AR, MacGregor ID (1975) Chromite spinels from ultramafic xenoliths. Geochim Cosmochim Acta 39:937-945

Boyd FR (1971) Pargasite-spinel peridotite xenolith from the Wesselton Mine. Carnegie Inst Wash Yrbk 70:138-142

Carswell DA (1975) Primary and secondary phlogopites and clinopyroxenes in garnet lherzolite xenoliths. Phys Chem Earth $9: 417-429$

Carswell DA (1980) Mantle derived lherzolite nodules associated with kimperlite, carbonatite, and basalt magmatism: a review. Lithos 12:121-138

Clark SP, Ringwood AE (1964) Density distributions and constitution of the mantle. Rev Geophys 2:35-88
Cox KG, Bell JD, Pankhurst RJ (1979) The Interpretation of Igneous Rocks. Clowes, London, England, $450 \mathrm{pp}$

Donaldson CH (1978) Petrology of the uppermost upper mantle deduced from spinel lherzolite and harzburgite nodules at Calton Hill, Derbyshire. Contrib Mineral Petrol 65:363-377

Eggler DH (1977) The principle of the zone of invariant vapor composition: an example in the system $\mathrm{CaO}-\mathrm{MgO}-\mathrm{SiO}_{2}-$ $\mathrm{H}_{2} \mathrm{O}$ and implications for the mantle solidus. Carnegie Inst Wash Yrbk 76:428-435

Ellis DJ (1976) High pressure cognate inclusions in the Newer Volcanics of Victoria. Contrib Mineral Petrol 58:149-180

Engi $\mathrm{M}$ (1983) Equilibria involving $\mathrm{Al}-\mathrm{Cr}$ spinel: $\mathrm{Mg}-\mathrm{Fe}$ exchange with olivine. Experiments, thermodynamic analysis, and consequences for geothermometry. Amer J Sci 283-A : 29-71

Fabries J (1979) Spinel-olivine geothermometry in peridotites from ultramafic complexes. Contrib Mineral Petrol 69:329-336

Forbes WC, Starmer RJ (1974) Kaersutite is a possible source of alkali olivine basalts. Nature 250:209-210

Francis DM (1976) The origin of amphibole in lherzolite xenoliths from Nunivak Island, Alaska. J Petrol 17:357-378

Frey FA, Green DH (1974) The mineralogy, geochemistry, and origin of lherzolite inclusions in Victorian basanites. Geochim Cosmochim Acta 38:1023-1059

Fujii T, Scarfe CM (1982) Petrology of ultramafic nodules from West Kettle River, near Kelowna, southern British Columbia. Contrib Mineral Petrol 80:297-306

Ghent ED, Coleman RG, Hadley DG (1980) Ultramafic inclusions and host alkali olivine basalts of the southern coastal plain of the Red Sea, Saudi Arabia. Amer J Sci 280-A:499-527

Girod M, Dautria JM, de Giovanni R (1981) A first insight into the constitution of the upper mantle under the Hoggar area (southern Algeria): the lherzolite xenoliths in the alkali basalts. Contrib Mineral Petrol 77:66-73

Gregory RT, Coleman RG, Brown GF (1982) Cenozoic volcanic rocks of Saudi Arabia: evidence from the continent for a twostage opening of the Red Sea. Geol Soc Amer Abs Prog 14(7): 502

Henry DJ, Medaris LG (1980) Application of pyroxene and olivine-spinel geothermometers to spinel peridotites in southwestern Oregon. Amer J Sci 280-A:211-231

Herzberg CT (1978) Pyroxene geothermometry and geobarometry: experimental and thermodynamic evaluation of some subsolidus phase relations involving pyroxenes in the system $\mathrm{CaO}-$ $\mathrm{MgO}-\mathrm{Al}_{2} \mathrm{O}_{3}-\mathrm{SiO}_{2}$. Geochim Cosmochim Acta 42:945-957

Irvine TN (1965) Chromian spinel as a petrogenetic indicator, part 1, theory. Can J Earth Sci 2:648-672

Irvine TN, Baragar WRA (1971) A guide to the chemical classification of the common volcanic rocks. Can J Earth Sci 8:523-548

Irving AJ (1974) Pyroxene-rich ultramafic xenoliths in the Newer Basalts of Victoria, Australia. N Jb Miner Abh 120:147-167

Jaques A1, Green DH (1980) Anhydrous melting of peridotite at $0-15 \mathrm{~kb}$ pressure and the genesis of tholeiitic basalt. Contrib Mineral Petrol 73:287-310

Jenkins DM, Newton RC (1979) Experimental determination of the spinel peridotite to garnet peridotite inversion at $900^{\circ} \mathrm{C}$ and $1,000^{\circ} \mathrm{C}$ in the system $\mathrm{CaO}-\mathrm{MgO}-\mathrm{Al}_{2} \mathrm{O}_{3}-\mathrm{SiO}_{2}$, and at $900^{\circ} \mathrm{C}$ with natural garnet and olivine. Contrib Mineral Petrol 68:407-419

Jones AP, Smith JV, Dawson JB (1983) Glasses in mantle xenoliths from Olmani, Tanzania. J Geol 91:167-178

Kemp J, Gros Y, Prian J-P (1982) Geologic Map of the Mahd adh Dhahab quadrangle, sheet 23E, Kingdom of Saudi Arabia, Ministry of Petroleum and Mineral Resources, Kingdom of Saudi Arabia

Kuo L-C, Kirkpatrick RJ (1985) Dissolution of mafic minerals and its implications for the ascent velocities of peridotite-bearing basaltic magmas. J Geol 93:691-700

Lindsley DH (1983) Pyroxene thermometry. Amer Min 68:477-493

Maaløe S, Printzlau I (1979) Natural partial melting of spinel lherzolite. J Petrol 20:727-741

MacRae ND (1979) Silicate glasses and sulfides in ultramafic xeno- 
liths, Newer Basalts, Victoria, Australia. Contrib Mineral Petrol $68: 275-280$

Mercier J-CC (1980) Single-pyroxene thermobarometry. Tectonophys $70: 1-37$

Mercier J-CC, Nicolas A (1975) Textures and fabrics of uppermantle peridotites as illustrated by xenoliths from basalts. J Petrol 16:454-487

Millhollen GL, Irving AJ, Wyllie PJ (1974) Melting interval of peridotite with 5.7 percent water to 30 kilobars. J Geol $82: 575-587$

Mysen BO (1976) Experimental determination of some geochemical parameters relating to conditions of equilibration of peridotite in the upper mantle. Amer Min 61:677-683

Mysen BO, Boettcher AL (1975) Melting of hydrous mantle: II. Geochemistry of crystals and liquids formed by anatexis of mantle peridotite at high pressures and high temperatures as a function of controlled activities of water, hydrogen, and carbon dioxide. J Petrol 16:549-593

Nicholls IA (1974) Liquids in equilibrium with peridotitic mineral assemblages at high water pressures. Contrib Mineral Petrol $45: 289-316$

Obata $\mathrm{M}$ (1976) The Solubility of $\mathrm{Al}_{2} \mathrm{O}_{3}$ in orthopyroxenes in spinel and plagioclase peridotites and spinel pyroxenite. Am Min 61:804-816

O'Hara MJ, Richardson S, Wilson G (1971) Garnet peridotite stability and occurrence in crust and mantle. Contrib Mineral Petrol 32:48-68

O'Neill HStC (1981) The transition between spinel lherzolite and garnet lherzolite, and its use as a geobarometer. Contrib Mineral Petrol 77:185-194

Quick JE (1981) Petrology and petrogenesis of the Trinity Peridotite, an upper mantle diapir in the Eastern Klamath Mountains, northern California. J Geophys Res 86:11837-11863

Reed SJB (1975) Electron microprobe analysis. Cambridge Univ Press, Cambridge, England, $400 \mathrm{pp}$

Ringwood AE (1975) Composition and petrology of the Earth's Mantle. McGraw-Hill, New York, 618 pp

Roedder E (1965) Liquid $\mathrm{CO}_{2}$ inclusions in olivine-bearing nodules and phenocrysts from basalts. Amer Min 50:1746-1782
Roeder PL, Emslie RF (1970) Olivine-liquid equilibrium. Contrib Mineral Petrol 29:275-289

Rucklidge JD, Gasparrini EL (1969) Specifications of a complete program for processing electron microprobe data: EMPADR VII. Department of Geology, University of Toronto (unpublished circular)

Sachtleben Th, Seck HA (1981) Chemical control of Al-solubility in orthopyroxene and its application on pyroxene geothermometry. Contrib Mineral Petrol 78:157-165

Scarfe CM, Mysen BO, Rai CS (1979) Invariant melting behavior of mantle material: partial melting of two lherzolite nodules. EOS 60:401

Schmidt DL, Hadley DG, Brown GF (1982) Middle Tertiary continent rift and evolution of the Red Sea in southwestern Saudi Arabia. Saudi Arabian Deputy Ministry for Mineral Resources Open-file Report, USGS-OF-03-6, 56 pp

Stewart DC, Boettcher AL, Eggler DH (1979) Phase relations of kaersutite at upper mantle conditions: implications for its subsolidus origin in ultramafic nodules. EOS 60:418

Takahashi E, Kushiro I (1983) Melting of a dry peridotite at high pressures and basalt magma genesis. Amer Min 68:859-879

Tatsumi Y, Ishizaka K (1982) Origin of high-magnesian andesites in the Setouchi volcanic belt, southwest Japan, I. petrographical and chemical characteristics. Earth Planet Sci Lett 60:293-304

Varne R (1977) On the origin of spinel lherzolite inclusions in basaltic rocks from Tasmania and elsewhere. J Petrol 18:1-23

Vaughan AW (1985) Mantle xenoliths from Harrat al Kishb, Western Saudi Arabia. EOS 66:1114

Wells PRA (1977) Pyroxene thermometry in simple and comlex systems. Contrib Mineral Petrol 62:129-139

White RW (1966) Ultramafic inclusions in basaltic rocks from Hawaii. Contrib Mineral Petrol 12:245-314

Wood $\mathrm{BJ}$ (1978) The influence of $\mathrm{Cr}_{2} \mathrm{O}_{3}$ on the relationship between spinel- and garnet-peridotites. Extended Abstr 2nd Int Kimberlite Conf

Received April 20, 1984 / Accepted March 5, 1986 